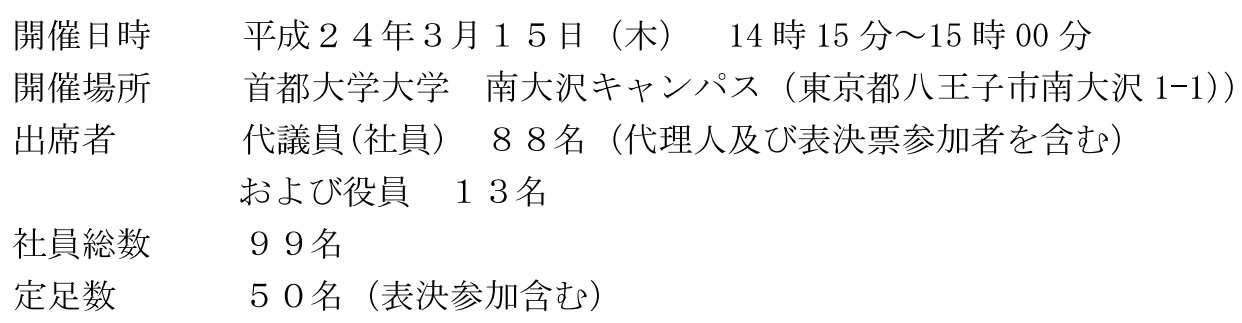

本会定款第 19 条により、総会開催の定足数は、表決参加も含め社員の過半数であり、 それを司会者の報告で確認した。これに従い、本総会は適法に成立したので定款に基づ き森脇 会長が議長となり、開会を宣し議事に入る。

議 事 1.2011 年度事業報告の件

水野理事より 2011 年度に実施した諸事業について別紙総会議案集「議案 $1 」$ のおり 報告され、審議した結果、議決権行使者の過半数の賛成によりこれを承認した。

議 事 2．２011 年度決算報告の件

小橋理事より 2011 年度決算について、また諸貫監事より監査結果について、それぞれ 別紙総会議案集「議案 $2 」$ のとおり 報告され、審議した結果、議決権行使者の過半数 の賛成によりこれを承認した。

議 事 3.2012 年度役員の件

高増理事より 2012 年度役員は、別紙総会議案集「議案 $3 」$ 」理事候補者、監事候補者 について候補者毎に報告され、候補者毎に審議した結果、候補者毎に議決権行使者の過 半数の賛成によりこれを承認した。

議 事 4.2012 年度事業計画の件

水野理事より 2012 年度事業計画について別紙総会議案集「議案 $4 」$ のおり説明があ り、審議した結果、議決権行使者の過半数の賛成によりこれを承認した。

議 事 5. 2012 年度収支予算の件

小橋理事より 2012 年度収支予算について別紙総会議案集「議案 $5 」$ のおり 説明があ り、審議した結果、議決権行使者の過半数の賛成によりこれを承認した。

議 事 6 . 名誉会員推薦の件

高増理事より定款第 5 条に基づき検討した結果について報告があり、議決権行使者の過 半数の賛成により下記の 3 名を名誉会員に推薦した。

稲崎一郎氏 小林 明発氏 嘉数 侑昇 氏 
本総会議事録が正確であることを証するため、定款第 22 条に基づき次の 2 名を署名人 に指定することに決定した。

1. 会 長 (議長)

森脇 俊道

2. 副会長

帯川 利之

平成 24 年 3 月 15 日

公益社団法人 精密工学会 2012 年度定時社員総会

署名人（議長）森脇 俊道

" （副会長） 帯川 利之 


\section{議 案 1 2011年度事業活動報告(平成23年2月1日～平成24年1月31日)}

I 精密工学に関する調査研究・啓発普及及び出版事業 (定款 4 条 1 項 $(1)) \cdots \ldots \ldots \ldots$.

(1) 機関誌その他刊行物の出版・発行

\begin{tabular}{|c|c|c|c|c|c|c|c|c|}
\hline \multirow[t]{9}{*}{ 定期刊行物 } & \multicolumn{8}{|c|}{$\begin{array}{l}\text { (1) 会誌「精密工学会誌 } 177 \text { 巻2号ー78巻1号 計 } 12 \text { 冊 } \\
\text { 論文·寄書 } 102 \text { 編,展望 } 13 \text { 編、解説 } 52 \text { 編、グラビアとインタビュー } 12 \text { 編、特集12編、 } \\
\text { シリーズ(私の歩んできた道、はじめての精密工学、受賞業績解説、国際会議報告、研究所研究室紹介) } \\
\text { 目次、アフィリエイト通信、トピックス, 学生記事、こぼれ話と苦労話、会告、会報、総目次、その他 } \\
\text { 総ページ } 1,154 \text { ページ(77巻12号まで学会誌DVDにも掲載) }\end{array}$} \\
\hline & 発行年月日 & 巻 & 号 & 発行部数 & 発行年月日 & 巻 & 号 & 発行部数 \\
\hline & 平成 23 年 2 月 5 日 & 77 & 2 & 4,920 & 平成 23 年 8 月 5 日 & 77 & 8 & 4,810 \\
\hline & 平成 23 年 3 月 5 日 & 77 & 3 & 4,920 & 平成23年 9 月 5 日 & 77 & 9 & 4,840 \\
\hline & 平成 23 年 4月 5日 & 77 & 4 & 4,930 & 平成 23 年 10 月 5 日 & 77 & 10 & 4,870 \\
\hline & 平成 23 年 5月 5 日 & 77 & 5 & 4,930 & 平成23年 11月 5日 & 77 & 11 & 4,900 \\
\hline & 平成 23 年 6 月 5 日 & 77 & 6 & 4,920 & 平成 23 年 12 月 5 日 & 77 & 12 & 4,910 \\
\hline & 平成 23 年 7 月 5 日 & 77 & 7 & 4,750 & 平成24年 1 月 5日 & 78 & 1 & 4,970 \\
\hline & \multicolumn{8}{|c|}{$\begin{array}{l}\text { (2) 欧文誌 "Precision Engineering" ASPE, euspen と共同編集 } \\
\text { Vol.35, No.1 〜 No.4 計4冊、総ページ 711ページ }\end{array}$} \\
\hline
\end{tabular}

(2) 調査研究・啓発普及に関寸る事業・委員会

\begin{tabular}{|c|c|c|}
\hline 1. 分科会 & $\begin{array}{l}\text { <2010年度より継続した分科会＞ } \\
\text { (1) サイバーフィールド構築技術研究分科会 } \\
\text { <2011年度に設置した分科会> } \\
\text { なしし }\end{array}$ & \\
\hline 2. 専門委員会 & 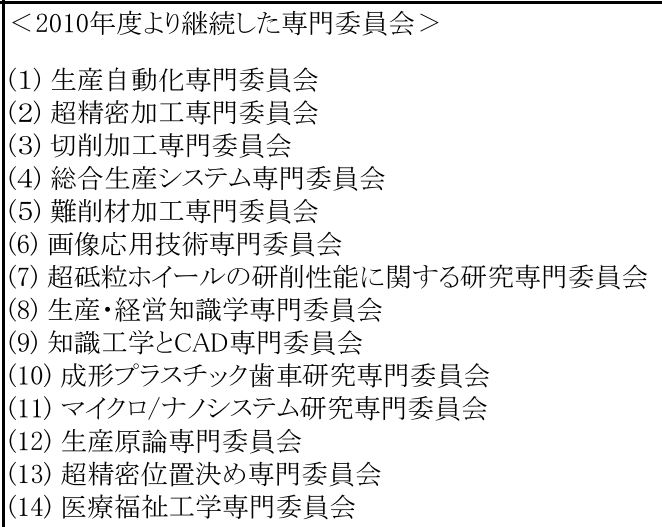 & 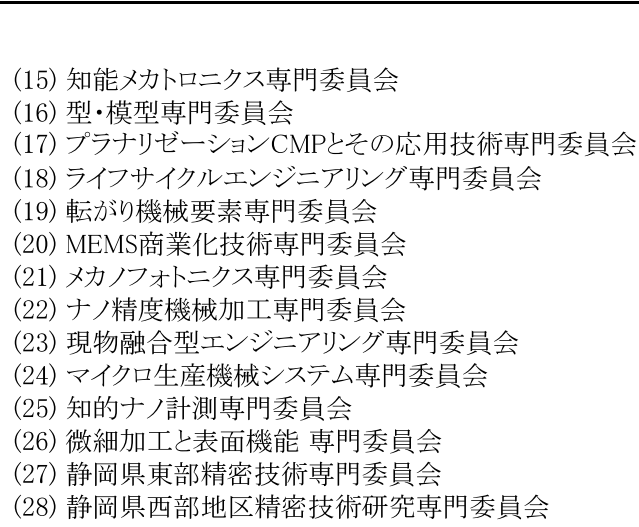 \\
\hline
\end{tabular}

II 精密工学に関する講演会等関連事業（定款 4 条 1 項 $(2)) \cdots \ldots \ldots \ldots \ldots \ldots$ 公2】

(1) 研究発表会、講演会、展覧会、講習会、見学会等の開催

\begin{tabular}{|c|c|c|c|}
\hline 1 学術講演会 & 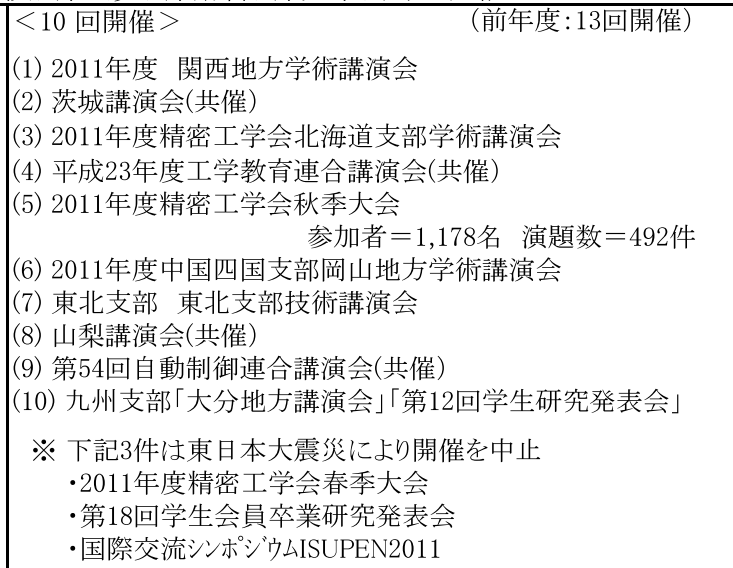 & $\begin{array}{l}\text { 平成 } 23 \text { 年 } \\
6 \text { 月30日 } \\
\text { 8月26日 } \\
\text { 9月 } 3 \text { 日 } \\
\text { 9月7日 } \\
\text { 9月20日 22日 } \\
\text { 10月8日 } \\
\text { 10月11日 } \\
\text { 10月22日 } \\
\text { 11月19日 20日 } \\
\text { 12月10、11日 }\end{array}$ & $\begin{array}{l}\text { 兵庫県立大学 } \\
\text { 茨城大学 } \\
\text { 公立はこだて未来大学 } \\
\text { 北海道大学 } \\
\text { 金沢大学 } \\
\text { 岡山大学 } \\
\text { 秋田大学 } \\
\text { 山梨大学 } \\
\text { 豊橋技術科学大学 } \\
\text { 大分大学 }\end{array}$ \\
\hline 2 国際会議 & $\begin{array}{l}<\text { 回開催 }>\quad \text { (前年度:7回開催) } \\
\text { (1)Int. Conf. on Optics in Precision Engi. and Nanotechnology } \\
\text { (ICOPEN2011)(企画協力) } \\
\text { (2) 第10回知的計算技術国際会議 (ISMTII2011) (共催) } \\
\text { (3) 㚳ロニクス\&オートメーショ国際会議 (IEEE ICMA2011)(企画協力) }\end{array}$ & 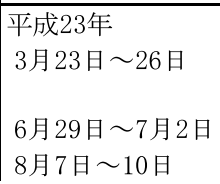 & $\begin{array}{l}\text { シンガポール } \\
\text { Daejeon (韓国) } \\
\text { 北京 (中国) }\end{array}$ \\
\hline
\end{tabular}




\begin{tabular}{|c|c|c|c|}
\hline & $\begin{array}{l}\text { (4) Int. sym. Micro/Nanomechatronics and Human Science } \\
\text { (MHS2011) (共催) } \\
\text { (5) Asian Society for Precision Engineering \& Nanotechnology } \\
\text { (ASPEN2011) (共催) } \\
\text { (6) Int. Conf. on Planarization/CMP Technology } 2011 \text { (共催) } \\
\text { (7) EcoDesign2011国際会議（共催） }\end{array}$ & $\begin{array}{l}\text { 11月 } 6 \text { 日〜9日 } \\
\text { 11月 } 16 \text { 日〜 18日 } \\
\text { 11月9日〜 } 11 \text { 日 } \\
\text { 11月30日 } ~ 12 \text { 月 } 2 \text { 日 }\end{array}$ & $\begin{array}{l}\text { 名古屋大学 } \\
\text { Hong Kong } \\
\text { ソウル (韓国) } \\
\text { 京都テレサ }\end{array}$ \\
\hline $\begin{array}{l}\text { 講習会、セミナー、愧話会、 } \\
\text { 研究会談 } \\
\text { 会 }\end{array}$ & 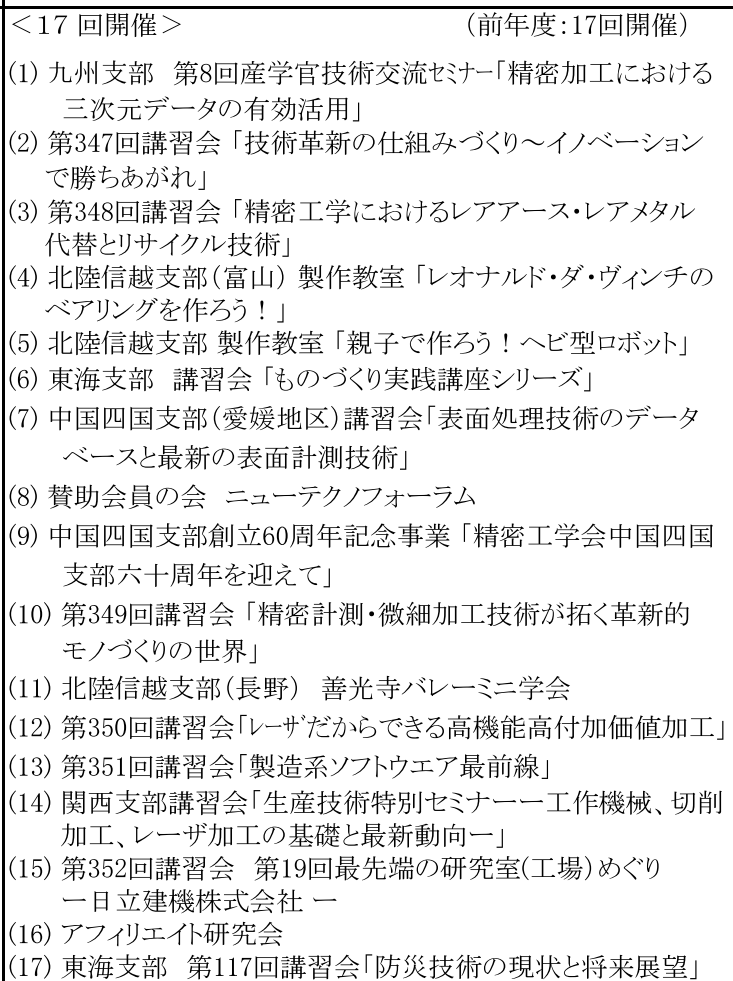 & 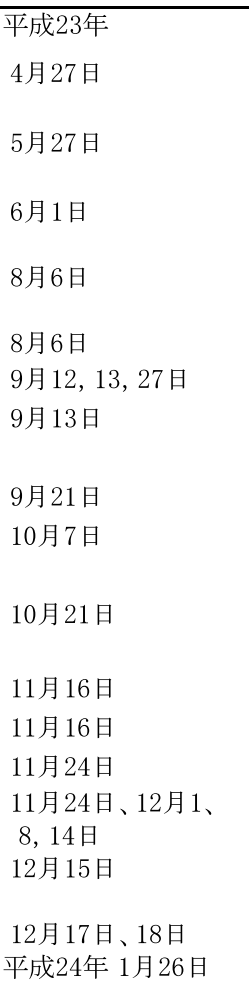 & $\begin{array}{l}\text { 九州工業大学 } \\
\text { 中央大学 } \\
\text { 東京電機大学 } \\
\text { 富山県立大学 } \\
\text { 国立長野工業専門学校 } \\
\text { 名古屋大学他 } \\
\text { 愛媛大学 } \\
\text { 金沢大学 } \\
\text { ピュアリティまきび } \\
\text { (森日立製作所 } \\
\text { 長野高専 地域共同テクハンター } \\
\text { キやンパス・インベーショセンター東京 } \\
\text { パシフィコ横浜 } \\
\text { 大阪市立大学 } \\
\text { 日立建機(㑣) } \\
\text { 熊本大学 } \\
\text { 名城大学 }\end{array}$ \\
\hline 4 特別講演 & 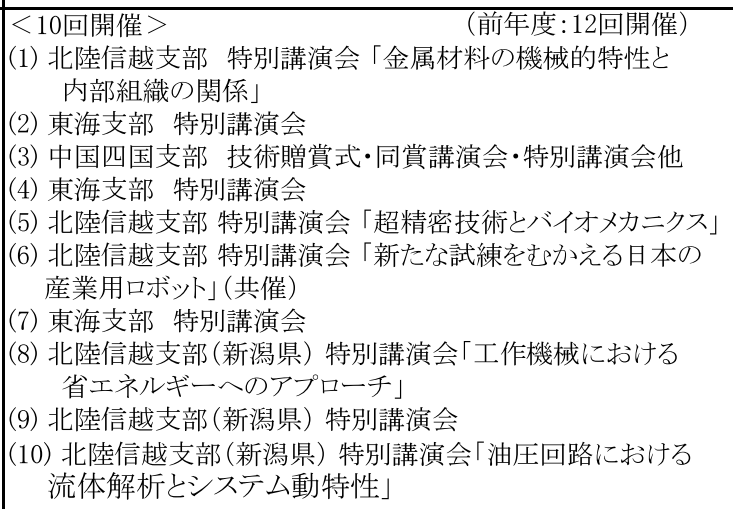 & $\begin{array}{l}\text { 平成23年 } \\
\text { 2月18日 } \\
\text { 3月1日 } \\
\text { 4月4日 } \\
\text { 5月20日 } \\
\text { 9月2日 } \\
\text { 10月3日 } \\
\text { 10月21日 } \\
\text { 11月1日 } \\
\text { 11月28日 } \\
\text { 平成24年1月17日 }\end{array}$ & $\begin{array}{l}\text { 金沢大学 } \\
\text { 中部大学 } \\
\text { 広島県情報プラザ } \\
\text { アイシン精機(森) } \\
\text { 信州大学 } \\
\text { 福井大学 } \\
\text { 新東工業(杵) } \\
\text { 長岡技術科学大学 } \\
\text { 新潟大学 } \\
\text { 金沢大学 }\end{array}$ \\
\hline 5 シンポジウム & 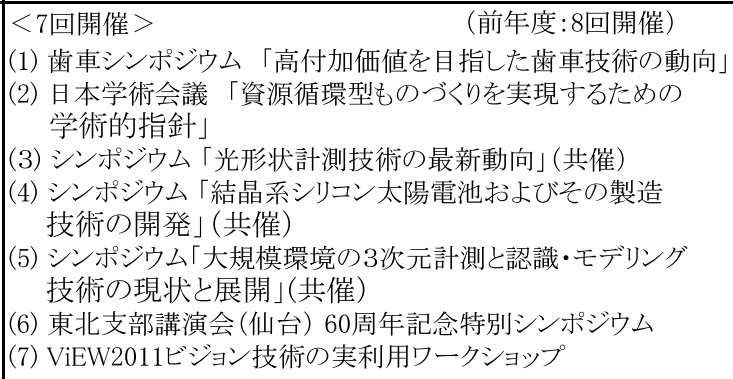 & $\begin{array}{l}\text { 平成23年 } \\
\text { 2月 } 8 \text { 日 } \\
7 \text { 月 } 7 \text { 日 } \\
\text { 9月 } 20 \text { 日 } \\
\text { 9月21日 } \\
\text { 9月 } 21 \text { 日 } \\
\text { 10月 21日 } \\
\text { 12月8〜9日 }\end{array}$ & $\begin{array}{l}\text { 名古屋市工業研究所 } \\
\text { 日本学術会議講堂 } \\
\text { 金沢大学 } \\
\text { 金沢大学 } \\
\text { 金沢大学 } \\
\text { ヴェスティンホテル仙台 } \\
\text { パシフィコ横浜 }\end{array}$ \\
\hline 6 見学会等 & $\begin{array}{ll}<3 \text { 回開催 }> & \text { (前年度:2回開催) } \\
\text { (1) 東海支部 見学会 } & \\
(2) \text { 関西支部 第14回見学会 } \\
\text { (3) 東海支部 見学会 }\end{array}$ & $\begin{array}{l}\text { 平成 } 23 \text { 年 } \\
5 \text { 月 } 20 \text { 日 } \\
10 \text { 月 } 20 \text { 日 } \\
10 \text { 月 } 21 \text { 日 } \\
\end{array}$ & 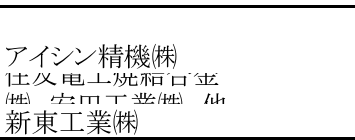 \\
\hline
\end{tabular}

(2) 内外の関係諸団体との連絡および提携

国内共催事業 (社)日本機械学会と本部で2件 [茨城講演会、山梨講演会]、支部で1件 [北陸信越支部:特別講演会]実施 学会連合での講演会3件 [工学教育連合、自動制御連合、EcoDesign] 実施

関連学協会催事に対寸る協賛·後援多数実施 (毎月約10件)

国際交流

26thASPE annual Meeting、11th International euspen Conference、ASPEN、CIRP、その他 
III 精密工学に関する奨励・顕彰等事業（定款 4 条 1 項(3)) $\ldots \ldots \ldots \ldots \ldots \ldots \ldots$ 【公3 】

表彰に関する事項

\begin{tabular}{|c|c|c|}
\hline \multirow{5}{*}{$\begin{array}{c}\text { 1. 精密工学会 } \\
\text { 論文賞 }\end{array}$} & \multicolumn{2}{|l|}{ (1) 2010年度 (第7回)精密工学会論文賞の審查および贈賞 } \\
\hline & \begin{tabular}{|c|} 
受 賞 業 績 \\
\end{tabular} & 受 賞 者 \\
\hline & $\begin{array}{l}\text { 大規模点群データの平滑化手法に関する研究(第1報) } \\
\text {-ロバスト推定に基づく平滑化手法一 }\end{array}$ & $\begin{array}{ll}\text { 増田 宏 } & \text { (東京大学) } \\
\text { 村上 健治 } & \text { (東京大学) }\end{array}$ \\
\hline & $\begin{array}{l}\text { 周波数可変ダイオードレーザを光源とする位相変調ホモダイン } \\
\text { 変位計測干渉計一第1報:要素技術の開発一 }\end{array}$ & \begin{tabular}{|ll} 
石下 雅史 & (長岡技術科学大学) \\
松浦 文生 & (長岡技術科学大学) \\
河杉 正晃 & (長岡技術科学大学) \\
星野 雄太 & (長岡技術科学大学) \\
バンクォクトゥン & (長岡技術科学大学) \\
明田川 正人 & (長岡技術科学大学)
\end{tabular} \\
\hline & 切削抵抗動的成分による工具－被削材間の凝着性評価 & $\begin{array}{ll}\text { 手塚 亮 } & \text { (広島大学) } \\
\text { 関谷 克彦 } & \text { (広島大学) } \\
\text { 山田 啓司 } & \text { (広島大学) } \\
\text { 山根 八洲男 } & \text { (広島大学) }\end{array}$ \\
\hline \multirow{4}{*}{$\begin{array}{l}\text { 2. 精密工学会沼田 } \\
\text { 記念論文賞 }\end{array}$} & \multicolumn{2}{|l|}{ (1) 2010年度 (第27回)精密工学会沼田記念論文賞の審查および贈賞 } \\
\hline & 受 賞 業 績 & 受 賞 者 \\
\hline & $\begin{array}{l}\text { Design and construction of a two-degree-of-freedom linear } \\
\text { encoder for nanometric measurement of stage position and } \\
\text { straightness }\end{array}$ & $\begin{array}{l}\text { (東北大学) } \\
\text { (東北大学) } \\
\text { (東北大学) } \\
\text { (清華大学 })\end{array}$ \\
\hline & $\begin{array}{l}\text { Machining tests to identify kinematic errors on five-axis } \\
\text { machine tools }\end{array}$ & $\begin{array}{l}\text { (京都大学) } \\
\text { (京都大学) } \\
\text { (京都大学) } \\
\text { (オークマ(株) }\end{array}$ \\
\hline \multirow{3}{*}{\begin{tabular}{r|} 
3. 精密工学会 \\
高城賞
\end{tabular}} & \multicolumn{2}{|l|}{ (1) 2010年度 (第13回)精密工学会高城賞の審査および贈賞 } \\
\hline & \begin{tabular}{|c|} 
受 賞 業 績 \\
\end{tabular} & \begin{tabular}{|c|} 
受 賞 者 \\
\end{tabular} \\
\hline & \begin{tabular}{|l} 
リエンンラントフローショップにおける装置メンテナンス計画に \\
関する研究(第2報)ー多スタート・グリーディ法の適用と実証試験 -
\end{tabular} & 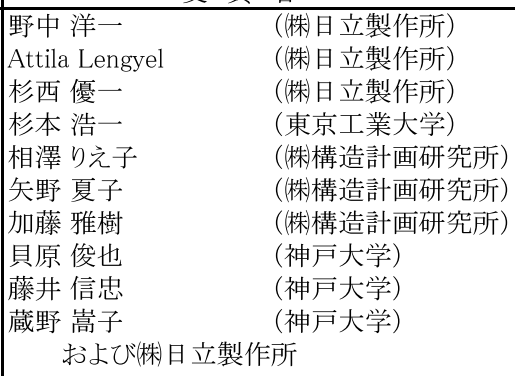 \\
\hline \multirow{6}{*}{$\begin{array}{l}\text { 4. 精密工学会 } \\
\text { 研究奨励賞 }\end{array}$} & \multicolumn{2}{|l|}{ (1) 2010年度(第7回)精密工学会研究奨励賞の審査および贈賞 } \\
\hline & \begin{tabular}{|c|} 
受 賞 業 績 \\
\end{tabular} & 受 賞 者 \\
\hline & $\begin{array}{l}\text { CWレーザ背面照射法 (CW-LBI)によるガラスの内部変質(第3報) } \\
\text { ーガラス内部への白金微粒子の導入一 }\end{array}$ & （東京工業大学） \\
\hline & \begin{tabular}{|c} 
体外循環用磁気浮上使い捨て遠心血液ポンプ \\
－動物実験に向けたポンプ性能向上-
\end{tabular} & （東京工業大学） \\
\hline & 静電誘導給電法を用いた放電加工の微細化 & （東京農工大学） \\
\hline & $\begin{array}{l}\text { PVDコーテイング工具による難削材の高能率・高精度切削(第1報) } \\
\text { - UBMS法によるTiCNコーテイングエンドミルを用いた } \\
\text { SUS304の高速乾式切削 - }\end{array}$ & （金沢大学） \\
\hline \multirow[t]{3}{*}{$\begin{array}{r}\text { 5. 精密工学会 } \\
\text { 技術賞 }\end{array}$} & \multicolumn{2}{|l|}{$\begin{array}{l}\text { (1) 2011年度(第31回)精密工学会技術賞の審査および贈賞 } \\
\text { 贈賞式 平成23年9月21日(水) 隹沢大学 }\end{array}$} \\
\hline & \begin{tabular}{|c|} 
受 賞 業 績 \\
\end{tabular} & 受 賞 者 \\
\hline & FPDプロセス用超大型·超精密位置決めステージの研究開発 & 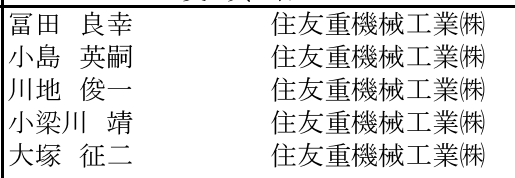 \\
\hline
\end{tabular}




\begin{tabular}{|c|c|c|c|}
\hline & |多波長ワンショット干渉計測技術の開発と実用化 & $\begin{array}{lll}\text { 北川 } & \text { 克一 } \\
\text { 坪井 } & \text { 辰彦 } \\
\text { 杉原 } & \text { 洋樹 } \\
\text { 杉山 } & \text { 将 } \\
\text { 小川 } & \text { 英光 }\end{array}$ & $\begin{array}{l}\text { 東レエンジニアリング株) } \\
\text { 東レエンジニアリング株) } \\
\text { 東レ(㑣) } \\
\text { 東京工業大学 } \\
\text { 東京福祉大学 }\end{array}$ \\
\hline & バインダレスナノ多結晶ダイヤモンドの実用化開発 & $\begin{array}{l}\text { 角谷 均 } \\
\text { 原野 佳津子 } \\
\text { 佐藤 武 }\end{array}$ & $\begin{array}{l}\text { 住友電気工業(㑣) } \\
\text { 住友電気工業(㑣) } \\
\text { 住友電気工業(㑣) }\end{array}$ \\
\hline $\begin{array}{r}6 . \text { 精密工学会 } \\
\text { 技術奨励賞 }\end{array}$ & $\begin{array}{l}\text { (1) 2011年度 (第7回)精密工学会技術奨励賞の審査および贈賞 } \\
\text { 贈賞式 平成23年9月21日 (水) 金沢大学 }\end{array}$ & & \\
\hline & 受 賞 業 績 & & 者 \\
\hline & 弾性表面波による微細気泡の発生 & \begin{tabular}{|l}
$\mid$ 岡野 正紀 \\
石上 陽平
\end{tabular} & $\begin{array}{l}\text { パナソニック電工(株) } \\
\text { パナソニック電工(株) }\end{array}$ \\
\hline & 内面形状計測用の小型三次元プローブカメラの開発 & 若山 俊隆 & 埼玉医科大学 \\
\hline & $\begin{array}{l}\text { 電界非接触擋拌技術を用いた迅速・高品位なハイブリダイ } \\
\text { ゼーション技術 および 抗原抗体反応技術の開発 }\end{array}$ & 加賀谷 昌美 & 秋田県産業技術センター \\
\hline & $\begin{array}{l}\text { 全空間テーブル化手法を啇用した光源切替位相シフト法による } \\
\text { 三次元形状計測の研究 }\end{array}$ & 柾谷 明大 & 和歌山大学 \\
\hline 7. 精密工学会賞 & (1) 2011年度(第7回)精密工学会賞の審査および贈賞 & & 者 \\
\hline & 贈賞式 平成23年9月21日 (水) 金沢大学 & \begin{tabular}{|l} 
木村文彦 \\
稲葉善治
\end{tabular} & $\begin{array}{l}\text { (法政大学、東大名誉教授) } \\
\text { (ファナク侏) }\end{array}$ \\
\hline
\end{tabular}

IV その他本法人の目的を達成するために必要な事業（定款4条1項(4)）

連絡・調整および審議に関する委員会等

\begin{tabular}{|c|c|c|c|}
\hline $\begin{array}{l}\text { 1. 社員総会 } \\
\text { 2. 支部総会 } \\
\text { 3. 理事会 } \\
\text { 4. 業務執行委員会 } \\
\text { 5. 代議員会議 } \\
\text { 6. 支部役員会 } \\
\text { 7. 支部本部摡談会 }\end{array}$ & $\begin{array}{l}\text { 2011年度定時社員総会 } \\
\text { 2011年度支部総会 } \\
\text { 2011年度理事会 } \\
\text { 2011年度業務執行委員会 } \\
\text { 2011年度代議員会議 } \\
\text { 2011年度支部役員会 } \\
\text { 2011年度支部·本部隗談会 }\end{array}$ & $\begin{array}{l}3 \text { 月 } 29 \text { 日 (火) } \\
\quad \text { 各支部開催 } \\
6 \text { 回開催 } \\
5 \text { 回開催 } \\
9 \text { 月21日 (水) } \\
\quad \text { 各支部開催 } \\
9 \text { 月 } 20 \text { 日 (火) }\end{array}$ & $\begin{array}{l}\text { 東京理科大学 } \\
\text { 金沢大学 } \\
\text { 金沢大学 }\end{array}$ \\
\hline $\begin{array}{l}\text { 委員会に関する事項 } \\
\text { 1. 研究交流に関す } \\
\text { る委員会 }\end{array}$ & \begin{tabular}{|l} 
事業部会 \\
1) 事業企画委員会 \\
2) 研究協力委員会 \\
3) 学術交流委員会 \\
4) 国際交流委員会 \\
5)アフィリエイト委員会
\end{tabular} & & \\
\hline $\begin{array}{l}\text { 2. 出版に関する } \\
\text { 委員会 }\end{array}$ & $\begin{array}{l}\text { 出版部会 } \\
\text { 1) 会誌編集委員会 } \\
\text { 2) 校閲委員会 } \\
\end{array}$ & & \\
\hline $\begin{array}{l}\text { 3. 広報・情報に関 } \\
\text { する委員会 }\end{array}$ & \begin{tabular}{|l|l|} 
広報・情報部会 \\
1) 広報委員会 \\
2) 情報化委員会 \\
\end{tabular} & & \\
\hline 4. 賞に関する委員会 & $\begin{array}{l}\text { (1) 精密工学会賞推薦委員会および審査委員会 } \\
\text { (2) 精密工学会論文賞審查員会 } \\
\text { (3) 精密工学会研究獎励賞審查員会 } \\
\text { (4) 精密工学会沼田記念論文賞審查委員会 } \\
\text { (5) 精密工学会高城賞番査委員会 } \\
\text { (6) 精密工学会技術賞審查委員会 } \\
\text { (7) 精密工学会技術奨励賞審査委員会 }\end{array}$ & & \\
\hline 5. その他の委員会等 & $\begin{array}{l}\text { (1) 賞検討委員会、 } \\
\text { (2) 平成23年度フェロー選考委員会 } \\
\text { (3) 平成23年度アフィリエイ選考委員会 } \\
\text { (4)「賛助会員の会」運営委員会 } \\
\text { (5) ワーキンググループ活動 }(W G-1 \text { WG-5) }\end{array}$ & & \\
\hline
\end{tabular}

2011年度会員状況

\begin{tabular}{|c|c|c|c|c|c|c|c|c|c|c|c|c|}
\hline \multirow{2}{*}{ 年度末現在 } & \multirow{2}{*}{$\begin{array}{l}\text { 名誉 } \\
\text { 会 }\end{array}$} & \multirow{2}{*}{ 正会員 } & \multicolumn{6}{|c|}{ 賛助会員 } & \multirow{2}{*}{$\begin{array}{l}\text { 学 生 } \\
\text { 会 員 }\end{array}$} & \multirow{2}{*}{$\begin{array}{l}\text { 学生会員 } \\
\text { Web級 }\end{array}$} & \multirow{2}{*}{$\begin{array}{l}\text { 海 外 } \\
\text { 在 住 }\end{array}$} & \multirow[b]{2}{*}{ 合 計 } \\
\hline & & & $\begin{array}{l}\text { 特級 } \\
\text { AA }\end{array}$ & $\begin{array}{l}\text { 特級 } \\
\text { A }\end{array}$ & $\begin{array}{c}\text { 特級 } \\
\text { B }\end{array}$ & 1級 & 2級 & Web & & & & \\
\hline \multirow{2}{*}{$\begin{array}{c}2011 \text { 年度 }(\mathrm{A}) \\
\text { 平成 } 24 \text { 年1月31日 }\end{array}$} & \multirow{2}{*}{92} & \multirow{2}{*}{4,117} & 1 & 6 & 15 & 29 & 129 & 32 & \multirow{2}{*}{198} & \multirow{2}{*}{955} & \multirow{2}{*}{68} & \multirow{2}{*}{5,642} \\
\hline & & & \multicolumn{6}{|c|}{212} & & & & \\
\hline \multirow{2}{*}{$\begin{array}{c}2010 \text { 年度(B) } \\
\text { 平成 } 23 \text { 年1月 } 31 \text { 日 }\end{array}$} & \multirow{2}{*}{89} & \multirow{2}{*}{4,305} & 1 & 6 & 16 & 28 & 132 & 30 & \multirow{2}{*}{224} & \multirow{2}{*}{917} & \multirow{2}{*}{64} & \multirow{2}{*}{5,812} \\
\hline & & & & & & & & & & & & \\
\hline \multirow{2}{*}{$\begin{array}{c}\text { 会員の増減 } \\
(\mathrm{A}-\mathrm{B})\end{array}$} & \multirow{2}{*}{3} & \multirow{2}{*}{-188} & 0 & 0 & -1 & 1 & -3 & 2 & \multirow{2}{*}{-26} & \multirow{2}{*}{38} & \multirow{2}{*}{4} & \multirow{2}{*}{-170} \\
\hline & & & & & & & \\
\hline
\end{tabular}


議案2 2011年度決算報告の件

（1） 2011 年度(平成23年度)収支計算書

2011年 2月 1日から 2012年 1月 31日まで (単位:円)

\begin{tabular}{|c|c|c|c|}
\hline 科 目 & 予算額 & 決算額 & 差 異 \\
\hline [事業活動収支の部] & & & \\
\hline 【基本財産運用収入】 & $\underline{86,075}$ & $\underline{44,146}$ & $\underline{41,929}$ \\
\hline 基本財産受取利息収入 & 86,075 & 44,146 & 41,929 \\
\hline 【受取入会金収入】 & 110,000 & $\underline{92,600}$ & 17,400 \\
\hline 入会金収入 & 110,000 & 92,600 & 17,400 \\
\hline 【受取会費収入】 & $\underline{88,540,000}$ & $\underline{86,729,334}$ & $\underline{1,810,666}$ \\
\hline 正会員会費収入 & $49,845,000$ & $48,152,100$ & $1,692,900$ \\
\hline 賛助会員会費収入 & $34,695,000$ & $34,908,334$ & $\triangle 213,334$ \\
\hline 学生会員会費収入 & $4,000,000$ & $3,668,900$ & 331,100 \\
\hline 【調査研究分担金収入】 & $\underline{47,277,000}$ & $\underline{45,894,665}$ & $\underline{1,382,335}$ \\
\hline 調査研究分担金収入·個人会費 & $3,597,000$ & $3,928,000$ & $\overline{\triangle 331,000}$ \\
\hline 調査研究分担金収入・法人会費等 & $43,680,000$ & $41,966,665$ & $1,713,335$ \\
\hline 【出版事業収入】 & $\underline{26,890,000}$ & $\underline{24,311,098}$ & $\underline{2,578,902}$ \\
\hline 会誌広告料収入 & $5,500,000$ & $5,671,210$ & $\triangle 171,210$ \\
\hline 論文掲載料収入 & $12,240,000$ & $9,995,191$ & $2,244,809$ \\
\hline 会誌購読料収入 & $5,000,000$ & $4,331,950$ & 668,050 \\
\hline PE誌購読料収入 & $1,000,000$ & 784,000 & 216,000 \\
\hline 別刷代収入 & $1,380,000$ & 911,370 & 468,630 \\
\hline 有料収入会告料収入 & 720,000 & $1,230,000$ & $\triangle 510,000$ \\
\hline 著作権料収入 & $1,050,000$ & $1,387,377$ & $\triangle 337,377$ \\
\hline 【講演会事業収入】 & $\underline{48,584,000}$ & $\underline{41,684,972}$ & $\underline{6,899,028}$ \\
\hline 学術講演会収入 & $18,532,000$ & $19,913,269$ & $\triangle \overline{1,381,269}$ \\
\hline 春季大会収入 & $12,830,000$ & $5,404,000$ & $7,426,000$ \\
\hline 秋季大会収入 & $14,500,000$ & $13,938,703$ & 561,297 \\
\hline 講習会収入 & $2,660,000$ & $2,388,000$ & 272,000 \\
\hline 国際会議収入 & 0 & 0 & 0 \\
\hline 賛助会員の会収入 & 62,000 & 41,000 & 21,000 \\
\hline 【特別事業収入】 & $\underline{700,000}$ & $\underline{165,000}$ & $\underline{535,000}$ \\
\hline 周年行事収入 & 700,000 & 165,000 & 535,000 \\
\hline Desinシンポジウム2010 & 0 & 0 & 0 \\
\hline 【広報·情報事業収入】 & $\underline{768,900}$ & $\underline{758,700}$ & 10,200 \\
\hline HP広告掲載料収入 & 768,900 & 758,700 & 10,200 \\
\hline 【事業管理収入】 & $\underline{900,000}$ & $\underline{920,000}$ & $\triangle 20,000$ \\
\hline 事務分担金収入 & $\overline{900,000}$ & $\overline{900,000}$ & 0 \\
\hline 頒布手数料収入 & 0 & 20,000 & $\triangle 20,000$ \\
\hline 【受取補助金等収入】 & $1,450,000$ & $\underline{3,766,776}$ & $\triangle 2,316,776$ \\
\hline 国・地方自治体補助金収入 & 100,000 & 530,000 & $\triangle 430,000$ \\
\hline 国·地方自治体助成金収入 & 0 & 950,000 & $\triangle 950,000$ \\
\hline 財団法人等補助金収入 & $1,350,000$ & $1,097,400$ & 252,600 \\
\hline 一般寄付金等収入 & 0 & $1,189,376$ & $\triangle 1,189,376$ \\
\hline 【雑収入】 & $\underline{296,928}$ & $\underline{836,197}$ & $\triangle 539,269$ \\
\hline 運用財産受取利息収入 & 216,928 & 124,729 & 92,199 \\
\hline 雑収入 & 30,000 & 24,400 & 5,600 \\
\hline 雑収入（義援金） & 0 & 538,568 & $\triangle 538,568$ \\
\hline 削除者会費収入 & 50,000 & 148,500 & $\triangle 98,500$ \\
\hline 事業活動収入計 & $215,602,903$ & $205,203,488$ & $10,399,415$ \\
\hline 【出版事業費支出】 & $\underline{47,933,500}$ & $\underline{37,351,772}$ & $\underline{10,581,728}$ \\
\hline 〔出版部会費支出〕 & 640,000 & 496,372 & 143,628 \\
\hline 〔編集委員会費支出〕 & $38,233,000$ & $32,697,059$ & $5,535,941$ \\
\hline 〔校閲委員会費支出〕 & $2,197,000$ & $1,234,460$ & 962,540 \\
\hline 〔編集管理費支出〕 & $4,643,500$ & $1,579,305$ & $3,064,195$ \\
\hline 〔PE購読費支出〕 & $2,220,000$ & $1,344,576$ & 875,424 \\
\hline 【講演会事業費支出】 & $\underline{115,188,740}$ & $\underline{96,281,997}$ & $\underline{18,906,743}$ \\
\hline 学術講演会等事業費支出 & $79,443,740$ & $66,257,317$ & $13,186,423$ \\
\hline 事業部会費支出 & $1,060,000$ & 690,268 & 369,732 \\
\hline 活動支援費支出 & 695,000 & 383,700 & 311,300 \\
\hline 関連諸経費支出 & 780,000 & 409,514 & 370,486 \\
\hline 春季大会費支出 & $9,250,000$ & $5,580,392$ & $3,669,608$ \\
\hline 秋季大会費支出 & $15,400,000$ & $14,729,407$ & 670,593 \\
\hline 講習会費支出 & $1,610,000$ & $2,079,227$ & $\triangle 469,227$ \\
\hline 国際会議費支出 & $1,350,000$ & 382,900 & 967,100 \\
\hline 研究会運営費支出 & 200,000 & 198,991 & 1,009 \\
\hline 業務委託費支出 & $5,400,000$ & $5,570,281$ & $\triangle 170,281$ \\
\hline
\end{tabular}




\begin{tabular}{|c|c|c|c|}
\hline 科 目 & 予算額 & 決算額 & 差 異 \\
\hline 【特別事業費支出】 & $3,080,000$ & $1,625,999$ & $1,454,001$ \\
\hline 周年行事費支出 & $3,080,000$ & $1,087,431$ & $1,992,569$ \\
\hline 特別事業費支出(義援金) & 0 & 538,568 & $\triangle 538,568$ \\
\hline 【広報·情報事業費支出】 & $\underline{2,847,400}$ & $\underline{2,150,140}$ & $\underline{697,260}$ \\
\hline 〔広報部会費支出〕 ～～～～～～ & $1,027,000$ & $1,233,243$ & $\triangle \overline{206,243}$ \\
\hline 〔情報関連費支出〕 & $1,820,400$ & 916,897 & 903,503 \\
\hline 【表彰費支出】 & $\underline{2,920,000}$ & $\underline{2,462,692}$ & $\underline{457,308}$ \\
\hline 【事業費支出】 & $56,839,138$ & $54,000,149$ & $2, \overline{838,989}$ \\
\hline 〔事業人件費〕 & $\overline{34,087,310}$ & $\overline{31,494,003}$ & $\overline{2,593,307}$ \\
\hline 〔会員管理費支出] & $3,317,000$ & $3,076,974$ & 240,026 \\
\hline 〔事業諸経費支出〕 & $19,434,828$ & $19,429,172$ & 5,656 \\
\hline 【管理費支出】 & $12,513,001$ & $\underline{11,530,000}$ & $\underline{983,001}$ \\
\hline [管理人件費支出] & $6,869,416$ & $7,207,903$ & $\triangle \overline{338,487}$ \\
\hline 〔理事会費支出〕 & $3,840,000$ & $3,219,842$ & 620,158 \\
\hline [その他管理費支出] & $1,803,585$ & $1,102,255$ & 701,330 \\
\hline 事業活動支出計 & $241,321,779$ & $205,402,749$ & $35,919,030$ \\
\hline 事業活動収支差額 & $\triangle 25,718,876$ & $\triangle 199,261$ & $\triangle 25,519,615$ \\
\hline 〔投資活動収支の部〕 & & & \\
\hline 【特定引当資産取崩収入】 & $\underline{18,050,000}$ & $\underline{18,050,000}$ & $\underline{0}$ \\
\hline 【その他特定資産取崩収入】 & $\underline{18,050,000}$ & $\underline{18,050,000}$ & $\underline{0}$ \\
\hline 資金平準化積立資産取崩収入 & $10,000,000$ & $10,000,000$ & 0 \\
\hline 特別事業積立資産取崩収入 & & & 0 \\
\hline $\begin{array}{l}\text { 事務研修積立資産取崩収入 } \\
\text { 事務近代化積立資産取崩収入 }\end{array}$ & & & 0 \\
\hline 支部活動費積立資産取崩収入 & $6,850,000$ & $6,850,000$ & 0 \\
\hline 専門委員会等活動費積立資産取崩収入 & $1,200,000$ & $1,200,000$ & 0 \\
\hline 投資活動収入計 & $18,050,000$ & $18,050,000$ & 0 \\
\hline 【特定引当資産取得支出】 & $\underline{9,151,080}$ & $\underline{10,751,080}$ & $\underline{0}$ \\
\hline 【基本財産取得支出】 & $\underline{721,080}$ & 721,080 & $\underline{0}$ \\
\hline 退職給付引当資産取得支出 & 721,080 & 721,080 & 0 \\
\hline 【基本財産取得支出】 & $\underline{0}$ & $\underline{0}$ & $\underline{0}$ \\
\hline 別途積立資産取得支出 & $\overline{0}$ & 0 & 0 \\
\hline 【特定積立資産(A)取得支出】 & $\underline{1,550,000}$ & $1,550,000$ & $\underline{0}$ \\
\hline 会員DBシステム更改用積立資産取得支出 & 750,000 & 750,000 & 0 \\
\hline オフィスPC更改用積立資産取得支出 & 250,000 & 250,000 & 0 \\
\hline オフィス環境整備積立資産取得支出 & 550,000 & 550,000 & 0 \\
\hline 【特定積立資産 (B)取得支出】 & $\underline{6,580,000}$ & $\underline{6,580,000}$ & $\underline{0}$ \\
\hline 第14回ICPE国際会議費積立支出 & $\overline{2,500,000}$ & $\overline{2,500,000}$ & $\overline{0}$ \\
\hline 精密工学会85周年事業費資金積立支出 & $1,500,000$ & $1,500,000$ & 0 \\
\hline 第6回ASPEN国際会議費積立支出 & $1,080,000$ & $1,080,000$ & 0 \\
\hline 東海支部60周年記念事業費積立支出 & $1,500,000$ & $1,500,000$ & 0 \\
\hline 【その他特定資産取得支出】 & $\underline{300,000}$ & $\underline{1,900,000}$ & $\triangle 1,600,000$ \\
\hline 資金平準化積立資産取得支出 & & & 0 \\
\hline 特別事業積立資産取得支出 & & & 0 \\
\hline 事務研修積立資産取得支出 & & & 0 \\
\hline $\begin{array}{l}\text { 事務近代化積立資産取得支出 } \\
\text { 支部䚾動弗皘次産取得古 }\end{array}$ & & 700000 & $\begin{array}{r}0 \\
\wedge \operatorname{sen} 000\end{array}$ \\
\hline $\begin{array}{l}\text { 支部活動費樍立資産取得支出 } \\
\text { 専門委員会等活動費積立資産取得支出 }\end{array}$ & 300,000 & $\begin{array}{r}700,000 \\
1,200,000\end{array}$ & $\begin{array}{r}\triangle 400,000 \\
\triangle 1,200,000\end{array}$ \\
\hline 投資活動支出計 & $9,151,080$ & $10,751,080$ & $\triangle 1,600,000$ \\
\hline 投資活動収支差額 & $8,898,920$ & $7,298,920$ & $1,600,000$ \\
\hline 【予備費支出】 & 0 & 0 & 0 \\
\hline 当期収支差額 & $\triangle 16,819,956$ & $7,099,659$ & $\triangle 9,720,297$ \\
\hline 前期繰越収支差額 & $75,455,711$ & $75,455,711$ & 0 \\
\hline 次期繰越収支差額 & $58,635,755$ & $82,555,370$ & $\triangle 23,919,615$ \\
\hline
\end{tabular}

特定積立資産 $(A)$ は特定資産取得資金、特定積立資産 $(B)$ は特定費用準備資金 
（2） 2011 年度 (平成23年度)収支計算書（総括表）

2011年2月1日から2012年1月31日まで

(単位:円)

\begin{tabular}{|c|c|c|c|c|c|c|}
\hline \multirow[t]{2}{*}{ 科 目 } & \multirow[t]{2}{*}{ 本部会計 } & \multirow{2}{*}{$\begin{array}{l}\text { 支部 } \\
\text { 会計 }\end{array}$} & \multirow{2}{*}{$\begin{array}{c}\text { 専門委員会 } \\
\text { 会計 }\end{array}$} & \multicolumn{2}{|c|}{ 内部取引調整額 } & \multirow[t]{2}{*}{ 合 計 } \\
\hline & & & & 借方 & 貸方 & \\
\hline \multicolumn{7}{|l|}{ 事業活動収支の部 } \\
\hline 基本財産利息収入 & 44,146 & & & & & 44,146 \\
\hline 入会金会費収入 & $86,821,934$ & & & & & $86,821,934$ \\
\hline 支部活動費受入金収入 & & $6,765,000$ & & $6,765,000$ & & 0 \\
\hline 調查研究分担金収入 & & & $45,894,665$ & & & $45,894,665$ \\
\hline 出版事業収入 & $24,311,098$ & & & & & $24,311,098$ \\
\hline 講演会事業収入 & $12,509,367$ & $18,582,953$ & $14,518,119$ & $3,925,467$ & & $41,684,972$ \\
\hline 特別事業収入 & & 165,000 & & & & 165,000 \\
\hline 広報・情報事業収入 & 821,700 & & & 63,000 & & 758,700 \\
\hline 事業管理収入 & $1,270,000$ & & & 350,000 & & 920,000 \\
\hline 補助金等収入 & $1,941,776$ & $1,525,000$ & 300,000 & & & $3,766,776$ \\
\hline 雑収入 & 814,813 & 3,692 & 17,692 & & & 836,197 \\
\hline 繰入金収入 & $1,900,000$ & $5,350,000$ & $1,200,000$ & $8,450,000$ & & 0 \\
\hline 事業活動収入計 & $130,434,834$ & $32,391,645$ & $61,930,476$ & $19,553,467$ & 0 & $205,203,488$ \\
\hline 出版事業費支出 & $37,351,772$ & & & & & $37,351,772$ \\
\hline 講演会事業費支出 & $16,183,008$ & $26,651,611$ & $57,965,845$ & & $4,518,467$ & $96,281,997$ \\
\hline 特別事業費支出 & 538,568 & $1,087,431$ & & & & $1,625,999$ \\
\hline 広報·情報事業費支出 & $2,150,140$ & & & & & $2,150,140$ \\
\hline 表彰費支出 & $2,462,692$ & & & & & $2,462,692$ \\
\hline 事業費支出 & $60,081,149$ & & 504,000 & & $6,585,000$ & $54,000,149$ \\
\hline 管理費支出 & $10,603,276$ & 174,279 & 752,445 & & & $11,530,000$ \\
\hline 繰入金支出 & $6,550,000$ & 700,000 & $1,200,000$ & & $8,450,000$ & 0 \\
\hline 事業活動支出計 & $135,920,605$ & $28,613,321$ & $60,422,290$ & 0 & $19,553,467$ & $205,402,749$ \\
\hline 事業活動収支差額 & $\triangle 5,485,771$ & $3,778,324$ & $1,508,186$ & & & $\triangle 199,261$ \\
\hline 投資活動収支の部 & & & & & & \\
\hline その他積立固定資産取崩収入 & $18,050,000$ & & & & & $18,050,000$ \\
\hline 退職給付引当資産取得支出 & 721,080 & & & & & 721,080 \\
\hline 特定積立資産取得支出 (A) & $1,550,000$ & & & & & $1,550,000$ \\
\hline 特定積立資産取得支出 (B) & $6,580,000$ & & & & & $6,580,000$ \\
\hline その他積立固定資産取得支出 & $1,900,000$ & & & & & $1,900,000$ \\
\hline 投資活動収入計 & $18,050,000$ & 0 & 0 & 0 & 0 & $18,050,000$ \\
\hline 投資活動支出計 & $10,751,080$ & 0 & 0 & 0 & 0 & $10,751,080$ \\
\hline 投資活動収支差額 & $7,298,920$ & 0 & 0 & 0 & 0 & $7,298,920$ \\
\hline 予備費支出 & 0 & & & & & 0 \\
\hline 当期収支差額 & $1,813,149$ & $3,778,324$ & $1,508,186$ & 0 & 0 & $7,099,659$ \\
\hline 前期繰越収支差額 & $29,975,101$ & $7,300,863$ & $38,179,747$ & & & $75,455,711$ \\
\hline 次期繰越収支差額 & $31,788,250$ & $11,079,187$ & $39,687,933$ & 0 & 0 & $82,555,370$ \\
\hline
\end{tabular}


2011年 2月 1日から2012年 1月31日まで（単位：円）

\begin{tabular}{|c|c|c|c|}
\hline 科 目 & 当 年 度 & 前 年 度 & 増 \\
\hline 〔一般正味財産増減の部〕 & & & \\
\hline 〔経常増減の部〕 ～～～～～～～ & & & \\
\hline 〔経常収益〕 ～～～～～～～～～ & & & \\
\hline 【基本財産運用益】 & $\underline{44,146}$ & $\underline{90,146}$ & $\triangle 46,000$ \\
\hline 基本財産受取利息 & $\overline{44,146}$ & 90,146 & $\triangle 46,000$ \\
\hline 【受取入会金】 & $\underline{92,600}$ & 115,000 & $\triangle 22,400$ \\
\hline 入会金 & 92,600 & 115,000 & $\triangle 22,400$ \\
\hline 【受取会費】 & $\underline{86,729,334}$ & $\underline{88,425,799}$ & $\triangle 1,696,465$ \\
\hline 正会員会費 & $48,152,100$ & $49,854,500$ & $\triangle 1,702,400$ \\
\hline 賛助会員会費 & $34,908,334$ & $34,737,499$ & 170,835 \\
\hline 学生会員会費 & $3,668,900$ & $3,833,800$ & $\triangle 164,900$ \\
\hline 【調査研究分担金収入】 & $\underline{45,894,665}$ & $\underline{48,044,500}$ & $\triangle 2,149,835$ \\
\hline 調査研究分担金収入·個人会員 & $3,928,000$ & $4,084,500$ & $\triangle 156,500$ \\
\hline 調查研究分担金収入·法人会員等 & $41,966,665$ & $43,960,000$ & $\triangle 1,993,335$ \\
\hline 【出版事業収益】 & $24,311,098$ & $27,355,530$ & $\triangle 3,044,432$ \\
\hline 会誌広告料 & $5,671,210$ & $4,824,540$ & 846,670 \\
\hline 論文掲載料 & $9,995,191$ & $13,342,648$ & $\triangle 3,347,457$ \\
\hline 会誌購読料 & $4,331,950$ & $4,878,720$ & $\triangle 546,770$ \\
\hline P E 誌購読料 & 784,000 & $1,008,000$ & $\triangle 224,000$ \\
\hline 別刷代 ～～～～～～～ & 911,370 & $1,142,860$ & $\triangle 231,490$ \\
\hline 有料会告料 & $1,230,000$ & 795,000 & 435,000 \\
\hline 著作権料 & $1,387,377$ & $1,363,762$ & 23,615 \\
\hline 【講演会事業収益】 & $\underline{41,684,972}$ & $\underline{48,979,984}$ & $\triangle 7,295,012$ \\
\hline 学術講演会 & $\overline{19,913,269}$ & $21,381,859$ & $\triangle 1,468,590$ \\
\hline 春季大会 & $5,404,000$ & $12,613,000$ & $\triangle 7,209,000$ \\
\hline 秋季大会 & $13,938,703$ & $11,270,125$ & $2,668,578$ \\
\hline 講習会 & $2,388,000$ & $2,600,000$ & $\triangle 212,000$ \\
\hline 国際会議 & 0 & $1,115,000$ & $\triangle 1,115,000$ \\
\hline 賛助会員の会 & 41,000 & 0 & 41,000 \\
\hline 【特別事業収益】 & $\underline{165,000}$ & $\underline{2,872,660}$ & $\triangle 2,707,660$ \\
\hline 周年行事収入 & 165,000 & $1,820,160$ & $\triangle 1,655,160$ \\
\hline Desinジポジウム2010 & 0 & $1,052,500$ & $\triangle 1,052,500$ \\
\hline 【広報・情報事業収益】 & $\underline{758,700}$ & $\underline{569,700}$ & 189,000 \\
\hline HP広告掲載料 & 758,700 & 569,700 & 189,000 \\
\hline 【事業管理収益】 & $\underline{920,000}$ & $\underline{234,814}$ & 685,186 \\
\hline 事務分担金 & 900,000 & 230,000 & 670,000 \\
\hline 頒布手数料 & 20,000 & 4,814 & 15,186 \\
\hline 【受取補助金等】 & $\underline{3,766,776}$ & $\underline{7,487,650}$ & $\triangle 3,720,874$ \\
\hline 国 - 地方自治体補助金 & 530,000 & $4,898,000$ & $\triangle 4,368,000$ \\
\hline 国 -地方自治体助成金 & 950,000 & & 950,000 \\
\hline 財団法人等補助金 & $1,097,400$ & $2,564,650$ & $\triangle 1,467,250$ \\
\hline 一般寄付金等 & $1,189,376$ & 25,000 & $1,164,376$ \\
\hline 【雑収益】 & $\underline{836,197}$ & $\underline{327,608}$ & $\underline{508,589}$ \\
\hline 運用財産受取利息 & 124,729 & 248,930 & $\triangle 124,201$ \\
\hline 雑収益 & 24,400 & 12,678 & 11,722 \\
\hline 雑収益(義援金) & 538,568 & 0 & 538,568 \\
\hline 削除者会費 & 148,500 & 66,000 & 82,500 \\
\hline 経常収益計 & $205,203,488$ & $224,503,391$ & $\triangle 19,299,903$ \\
\hline
\end{tabular}




\begin{tabular}{|c|c|c|c|}
\hline 科 & 当 年 度 & 前 年 度 & 増 \\
\hline \multicolumn{4}{|l|}{ [経常費用] } \\
\hline 【出版事業費】 & $\underline{37,351,772}$ & $\underline{47,812,078}$ & $\triangle 10,460,306$ \\
\hline 〔出版部会費〕 & 496,372 & 525,752 & $\triangle 29,380$ \\
\hline 〔編集委員会費〕 & $32,697,059$ & $39,357,493$ & $\triangle 6,660,434$ \\
\hline [校閲委員会費] & $1,234,460$ & $1,425,554$ & $\triangle 191,094$ \\
\hline 〔編集管理費〕 & $1,579,305$ & $5,125,453$ & $\triangle 3,546,148$ \\
\hline 〔PE購読費〕 & $1,344,576$ & $1,377,826$ & $\triangle 33,250$ \\
\hline 【講演会事業費】 & $\underline{96,281,997}$ & $\underline{108,389,150}$ & $\triangle 12,107,153$ \\
\hline 学術講演会等事業費 & $66,257,317$ & $73,237,314$ & $\triangle 6,979,997$ \\
\hline 事業部会費 ～～～ & 690,268 & 532,850 & 157,418 \\
\hline 活動支援費 & 383,700 & 355,800 & 27,900 \\
\hline 関連諸経費 & 409,514 & 442,488 & $\triangle 32,974$ \\
\hline 春季大会費 & $5,580,392$ & $8,286,949$ & $\triangle 2,706,557$ \\
\hline 秋季大会費 & $14,729,407$ & $10,593,592$ & $4,135,815$ \\
\hline 講習会 & $2,079,227$ & $1,446,951$ & 632,276 \\
\hline 国際会議費 & 382,900 & $8,739,354$ & $\triangle 8,356,454$ \\
\hline 研究会運営費 & 198, 991 & 200,000 & $\triangle 1,009$ \\
\hline 業務委託費 & $5,570,281$ & $4,553,852$ & $1,016,429$ \\
\hline 【特別事業費】 & $\underline{1,625,999}$ & $2,986,589$ & $\triangle 1,360,590$ \\
\hline 周年行事費 & $\overline{1,087,431}$ & $\overline{1,934,089}$ & $\triangle 846,658$ \\
\hline 特別事業費 （義援金） & 538,568 & 0 & 538,568 \\
\hline Desinジポジウム2010費 & 0 & $1,052,500$ & $\triangle 1,052,500$ \\
\hline 【広報・情報事業費】 & $\underline{2,150,140}$ & $2,548,773$ & $\triangle 398,633$ \\
\hline 〔広報部会費〕 & $\overline{1,233,243}$ & 996,411 & 236,832 \\
\hline [情報関連費〕 & 916,897 & $1,552,362$ & $\triangle 635,465$ \\
\hline 【表彰費】 & $\underline{2,462,692}$ & $\underline{2,731,034}$ & $\triangle 268,342$ \\
\hline 【事業費】 & $\underline{54,607,481}$ & $\underline{58,621,451}$ & $\triangle \overline{4,013,970}$ \\
\hline [事業人件費] & $31,494,003$ & $34,300,419$ & $\triangle 2,806,416$ \\
\hline [会員管理費] & $3,076,974$ & $3,381,841$ & $\triangle 304,867$ \\
\hline [事業諸経費] & $20,036,504$ & $20,939,191$ & $\triangle 902,687$ \\
\hline 【管理費】 & $\underline{11,530,000}$ & $\underline{12,326,056}$ & $\triangle 796,056$ \\
\hline [管理人件費] & $7,207,903$ & $7,351,813$ & $\triangle 143,910$ \\
\hline 〔理事会費〕 & $3,219,842$ & $3,457,859$ & $\triangle 238,017$ \\
\hline [その他管理費] & $1,102,255$ & $1,516,384$ & $\triangle 414,129$ \\
\hline 経常費用計 & $206,010,081$ & $235,415,131$ & $\triangle 29,405,050$ \\
\hline 当期経常増減額 & $\triangle 806,593$ & $\triangle 10,911,740$ & $10,105,147$ \\
\hline \multicolumn{4}{|l|}{ 〔経常外増減の部〕 } \\
\hline 【引当金取崩額】 & $\underline{544,800}$ & $\underline{560,800}$ & $\triangle 16,000$ \\
\hline 退職給付引当金取崩額 & 0 & 0 & 0 \\
\hline 会費回収不能引当金取崩額 & 544,800 & 560,800 & $\triangle 16,000$ \\
\hline 経常外収益計 & 544,800 & 560,800 & $\triangle 16,000$ \\
\hline \multicolumn{4}{|l|}{ [経常外費用] } \\
\hline 【引当金繰入額】 & $\underline{1,166,680}$ & $\underline{575,520}$ & $\underline{591,160}$ \\
\hline 退職給付引当金繰入額 & 721,080 & $\overline{30,720}$ & $\overline{690,360}$ \\
\hline 会費回収不能引当金繰入額 & 445,600 & 544,800 & $\triangle 99,200$ \\
\hline 経常外費用計 & $1,166,680$ & 575,520 & 591,160 \\
\hline 当期経常外増減額 & $\triangle 621,880$ & $\triangle 14,720$ & $\triangle 607,160$ \\
\hline 税引き前当期一般正味財産増減額 & $\triangle 1,428,473$ & $\triangle 10,926,460$ & $9,497,987$ \\
\hline 当期一般正味財産増減額 & $\triangle 1,428,473$ & $\triangle 10,926,460$ & $9,497,987$ \\
\hline 一般正味財産期首残高 & $248,906,024$ & $259,832,484$ & $\triangle 10,926,460$ \\
\hline 一般正味財産期末残高 & $247,477,551$ & $248,906,024$ & $\triangle 1,428,473$ \\
\hline \multicolumn{4}{|l|}{ 〔指定正味財産の部〕 } \\
\hline 当期指定正味財産増加額 & $2,262,650$ & $4,300,000$ & $\triangle 2,037,350$ \\
\hline 当期指定正味財産减少額 & $2,262,650$ & $4,300,000$ & $\triangle 2,037,350$ \\
\hline 当期正味財産期首残高 & 0 & 0 & 0 \\
\hline 指定正味財産期末残高 & 0 & 0 & 0 \\
\hline 正味財産期末残高 & $247,477,551$ & $248,906,024$ & $\triangle 1,428,473$ \\
\hline
\end{tabular}


（4） 2011年度(平成23年度) 貸借対照表（総括表）

2012年 1月31日現在（単位:円)

\begin{tabular}{|c|c|c|c|c|}
\hline 科 & 本部会計 & 支部会計 & 専門委員会会計 & 合 計 \\
\hline \multirow{2}{*}{\multicolumn{5}{|c|}{$\begin{array}{l}\text { 【資産の部〕 } \\
\text { 【流動資産】 }\end{array}$}} \\
\hline & & & & \\
\hline 現金預金 & $86,862,604$ & $10,415,552$ & $37,945,309$ & $135,223,465$ \\
\hline 受取手形 & 970,780 & & & 970,780 \\
\hline 有価証券 & 224,664 & & & 224,664 \\
\hline 未収金 & $2,297,740$ & & $1,896,000$ & $4,193,740$ \\
\hline 前払金 & $5,454,828$ & 774,635 & & $6,229,463$ \\
\hline 立替金 & 151,890 & & & 151,890 \\
\hline 仮払金 & 0 & & 20,000 & 20,000 \\
\hline 会費回収不能引当金 & $\triangle 445,600$ & & & $\triangle 445,600$ \\
\hline 流動資産合計 & $95,516,906$ & $11,190,187$ & $39,861,309$ & $146,568,402$ \\
\hline \multicolumn{5}{|l|}{ 【固定資産】 } \\
\hline （基本財産） & & & & \\
\hline 基本金資産 & $4,430,000$ & & & $4,430,000$ \\
\hline 別途積立資産 & $30,000,000$ & & & $30,000,000$ \\
\hline 基本財産合計 & $34,430,000$ & 0 & 0 & $34,430,000$ \\
\hline \multicolumn{5}{|l|}{ （特定引当資産） } \\
\hline 退職給付引当資産 & $3,367,920$ & & & $3,367,920$ \\
\hline 特定引当資産合計 & $3,367,920$ & 0 & 0 & $3,367,920$ \\
\hline \multicolumn{5}{|l|}{ (特定積立資産) (A) } \\
\hline 会員DBシステム更改用積立資産 & $8,750,000$ & & & $8,750,000$ \\
\hline オフィスPC更改用積立資産 & $2,250,000$ & & & $2,250,000$ \\
\hline オフイス環境整備積立資産 & $6,550,000$ & & & $6,550,000$ \\
\hline 特定積立資産 (A)合計 & $17,550,000$ & 0 & 0 & $17,550,000$ \\
\hline \multicolumn{5}{|l|}{ (特定積立資産) (B) } \\
\hline 第14回ICPE国際会議積立資産 & $12,500,000$ & & & $12,500,000$ \\
\hline 精密工学会85周年記念事業積立資産 & $26,500,000$ & & & $26,500,000$ \\
\hline 第6回ASPEN国際会議積立資産 & $9,591,970$ & & & $9,591,970$ \\
\hline 東海支部60周年記念事業積立資産 & $3,000,000$ & & & $3,000,000$ \\
\hline 特定積立資産 (B)合計 & $51,591,970$ & 0 & 0 & $51,591,970$ \\
\hline 特定資産合計 & $72,509,890$ & 0 & 0 & $72,509,890$ \\
\hline \multicolumn{5}{|l|}{ （その他積立固定資産） } \\
\hline 資金平準化積立資産 & $7,500,000$ & & & $7,500,000$ \\
\hline 特別事業積立資産 & $4,000,000$ & & & $4,000,000$ \\
\hline 事務研修積立資産 & 700,000 & & & 700,000 \\
\hline 事務近代化積立資産 & $5,000,000$ & & & $5,000,000$ \\
\hline 支部活動費積立資産 & $14,378,217$ & & & $14,378,217$ \\
\hline 専門委員会等活動費積立資産 & $20,300,000$ & & & $20,300,000$ \\
\hline その他積立固定資産合計 & $51,878,217$ & 0 & 0 & $51,878,217$ \\
\hline \multicolumn{5}{|l|}{ （その他固定資産） } \\
\hline 建物付帯設備 & $1,156,500$ & & & $1,156,500$ \\
\hline 什器備品 & $10,710,101$ & & & $10,710,101$ \\
\hline 減価償却累計額 & $\triangle 10,668,287$ & & & $\triangle 10,668,287$ \\
\hline 電話加入権 & 79,880 & & & 79,880 \\
\hline 敷金 & $8,639,400$ & & & $8,639,400$ \\
\hline その他固定資産合計 & $9,917,594$ & 0 & 0 & $9,917,594$ \\
\hline 固定資産合計 & $168,735,701$ & 0 & 0 & $168,735,701$ \\
\hline 資 産 合 計 & $264,252,607$ & $11,190,187$ & $39,861,309$ & $315,304,103$ \\
\hline \multirow{2}{*}{\multicolumn{5}{|c|}{$\begin{array}{l}\text { 〔負債の部〕 } \\
\text { 【流動負債】 }\end{array}$}} \\
\hline & & & & \\
\hline 未払金 & $2,940,161$ & & 61,710 & $3,001,871$ \\
\hline 前受金 & $60,514,400$ & 111,000 & 105,000 & $60,730,400$ \\
\hline 預り金 & 705,065 & & 6,666 & 711,731 \\
\hline 仮受金 & 14,630 & & & 14,630 \\
\hline 流動負債合計 & $64,174,256$ & 111,000 & 173,376 & $64,458,632$ \\
\hline \multicolumn{5}{|l|}{ 【固定負債】 } \\
\hline 退職給付引当金 & $3,367,920$ & & & $3,367,920$ \\
\hline 固定負債合計 & $3,367,920$ & 0 & 0 & $3,367,920$ \\
\hline 負 債 合 計 & $67,542,176$ & 111,000 & 173,376 & $67,826,552$ \\
\hline \multicolumn{5}{|l|}{ 〔正味財産の部〕 } \\
\hline 【指定正味財産】 & 0 & 0 & 0 & 0 \\
\hline （うち基本財産への充当額） & 0 & 0 & 0 & 0 \\
\hline （うち特定资産への充当額） & 0 & 0 & 0 & 0 \\
\hline 指定正味財産合計 & 0 & 0 & 0 & 0 \\
\hline 【一般正味財産】 & $196,710,431$ & $11,079,187$ & $39,687,933$ & $247,477,551$ \\
\hline （うち基本財産への充当額） & $34,430,000$ & 0 & 0 & $34,430,000$ \\
\hline （うち特定資産への充当額） & $72,509,890$ & 0 & 0 & $72,509,890$ \\
\hline 一般正味財産合計 & $196,710,431$ & $11,079,187$ & $39,687,933$ & $247,477,551$ \\
\hline 正味財産合計 & $196,710,431$ & $11,079,187$ & $39,687,933$ & $247,477,551$ \\
\hline 負債及び正味財産合計 & $264,252,607$ & $11,190,187$ & $39,861,309$ & $315,304,103$ \\
\hline
\end{tabular}


（5）財産 目録

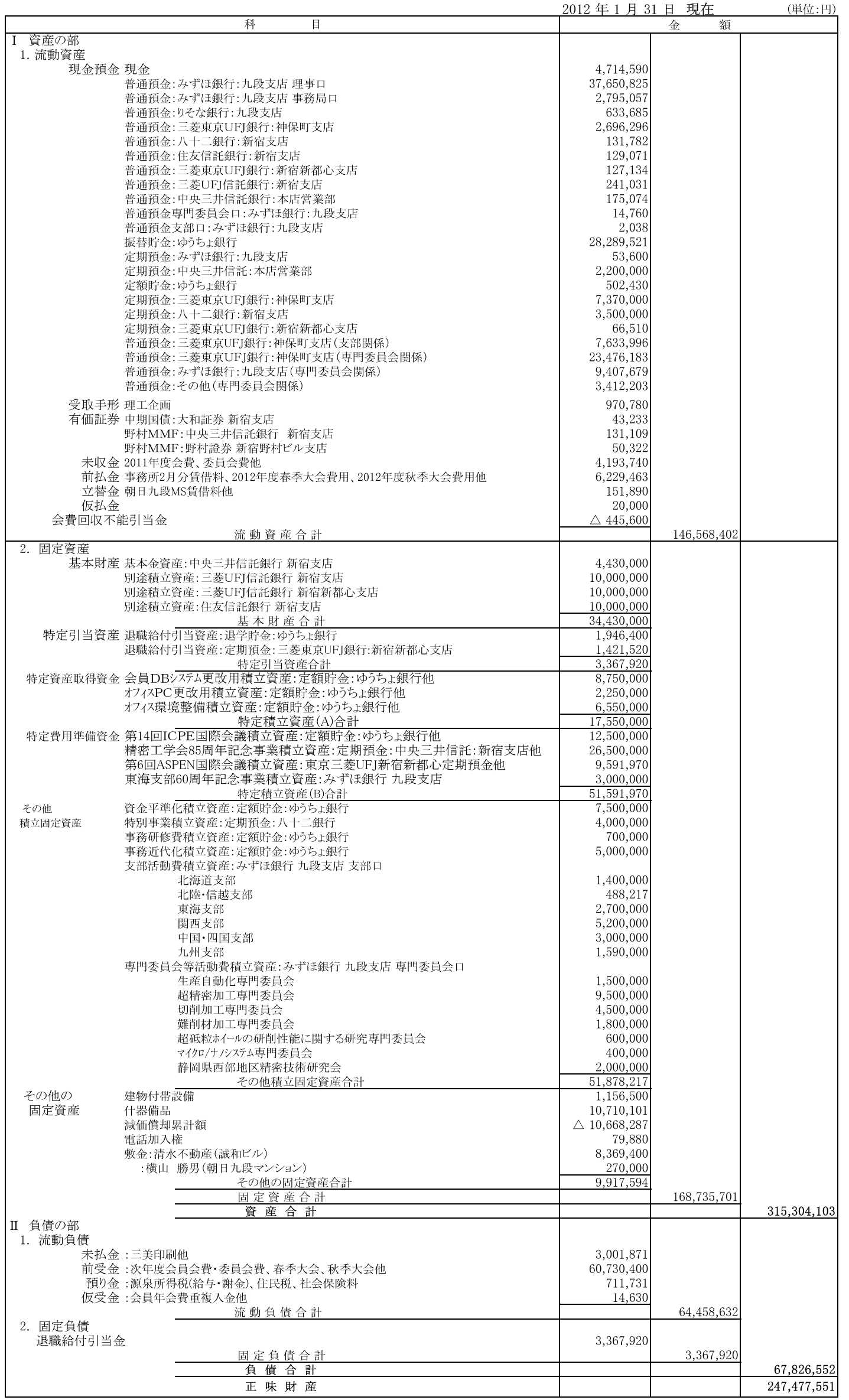


監查報 告 書

公益社団法人 精密工学会

会 長 森脇 俊道 殿

副会 長 帯川 利之 殿

副会 長 上田 修治 殿

庶務 理事 高増 潔 殿

会計理事 小橋 隆 殿

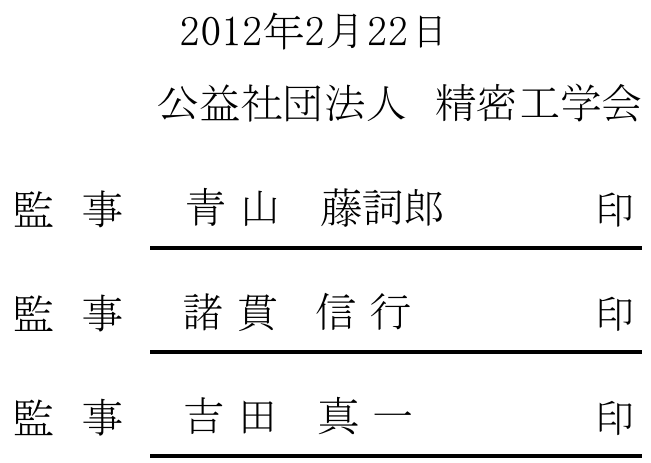

私達は、2011年2月1日から2012年1月31日までの会計年度の公益社団法人精密 工学会における業務執行状況及び貸借対照表、正味財産増減計算書、財産目録 など財務諸表ならびに関係諸帳票、証拠書類について監查しました結果、適法かつ 正確であることを認めます。 
議 案 3 2012年度精密工学会役員の件

<全て非常勤 $>$

任期: 2014年定時社員総会まで

理事候補者 (27名)

\begin{tabular}{|l|l|}
\hline 氏 名 & \multicolumn{1}{|c|}{ 所 属 } \\
\hline 石原 直 & 東京大学大学院 \\
\hline 笹島 和幸 & 東京工業大学大学院 \\
\hline 北嶋 弘一 & 関西大学 \\
\hline 鈴木 裕 & 九州工業大学 \\
\hline 青山 英樹 & 慶應義塾大学 \\
\hline 足立 幸志 & 東北大学大学院 \\
\hline 乾 正知 & 茨城大学 \\
\hline 太田 順 & 東京大学 \\
\hline 大竹 尚登 & 東京工業大学 大学院 \\
\hline 大谷 幸利 & 宇都宮大学 \\
\hline 梶田 敏治 & 日本精工㑣) \\
\hline 金枝 敏明 & 岡山理科大学 \\
\hline 金子 俊一 & 北海道大学 大学院 \\
\hline 岸 佐年 & 長野工業高等専門学校 \\
\hline 木山 精一 & 三洋電機株) \\
\hline 笹原 弘之 & 東京農工大 学大学院 \\
\hline 清水 滋 & TOTO(株) \\
\hline 杉村 延広 & 大阪府立大学 \\
\hline 須藤 雅子 & ファナック(株) \\
\hline 辻 裕之 & 日本ガイシ(株) \\
\hline 保坂 寛 & 東京大学大学院 \\
\hline 松木 則夫 & 産業技術総合研究所 \\
\hline 松村 隆 & 東京電機大学 \\
\hline 野村 俊 & 富山県立大学 \\
\hline 森田 昇 & 千葉大学大学院 \\
\hline 山本 優 & (株シギヤ精機製作所 \\
\hline 山本 秀彦 & 岐阜大学 \\
\hline
\end{tabular}

監事候補者 (3名)

\begin{tabular}{|c|c|}
\hline 氏名 & 所 属 \\
\hline 帯川 利之 & 東京大学 \\
\hline 水野 毅 & 埼玉大学 大学院 \\
\hline 吉田 真一 & 税理士事務所 \\
\hline
\end{tabular}




\section{議案 4 2012年度事業計画（平成24年2月1日～平成25年1月31日）}

\section{I 精密工学に関する調查研究・啓発普及及び出版事業（定款 4 条 1 項 (1) ) ・ ・【公 1 】}

(1) 学会誌「精密工学会誌」を下記のとおり発行する。

\begin{tabular}{|c|c|c|c|c|c|c|c|c|c|}
\hline 発行年月日 & & 巻 & 号 & 発行部数 & 発行年月日 & & 巻 & & 発行部偻 \\
\hline 平成24年 2 月 & 5 日 & 78 & 2 & 4,920 & 平成24年 8月 & 5 日 & 78 & 8 & 4,810 \\
\hline 4年 3月 & 5 日 & 78 & 3 & 4,920 & 平成 24 年 9 月 & 5 日 & 78 & & 4,840 \\
\hline 24年 4 月 & 5 日 & 78 & 4 & 4,930 & 平成 24 年 10 月 & 5 日 & & & 4,870 \\
\hline 24年 5 月 & 5 日 & 78 & 5 & 4,930 & 平成24年11月 & 5 日 & & & 4,900 \\
\hline 4 年 6 月 & 5 日 & & 6 & 4,920 & 平成 24 年 12 月 & 5 日 & & & 4,910 \\
\hline 成24年 7 & 5日 & & 7 & 475 & & 5 日 & & & 4,970 \\
\hline
\end{tabular}

(2) 欧文誌 "Precision Engineering"の編集をASPE，euspen と共同で行う。

Vol. 36 , No. $1 \sim$ No. 4 計 4 冊、総ページ 700ページ

(3) 調査研究・研究開発に関する委員会

1. 分科会

2. 専門委員会
$<2011$ 年度より継続する分科会 $>$ なし

$<2012$ 年度に設置する予定の分科会 $>$ なし

＜2011年度より継続する専門委員会＞

（1）生産自動化専門委員会

（2）超精密加工専門委員会

(3) 切削加工専門委員会

(4) 総合生産システム専門委員会

（5）難削材加工専門委員会

（6）画像応用技術専門委員会

（7）超砥粒ホイールの研削性能に関する研究専門委員会

(8) 生産・経営知識学専門委員会

(9) 知識工学とCAD専門委員会

(10) 成形プラスチック歯車研究専門委員会

(11） マイクロ/ナノシステム研究専門委員会

（12）生産原論専門委員会

（13）超精密位置決め専門委員会

（14）医療福祉工学専門委員会

（15）知能メカトロニクス専門委員会

（16）型・模型専門委員会

（17）プラナリゼーション加工/CMP応用技術専門委員会

(18）ライフサイクルエンジニアリング専門委員会

(19）転がり機械要素専門委員会

(20) MEMS商業化技術専門委員会

(21) メカノフォトニクス専門委員会

（22）十ノ精度機械加工専門委員会

（23）現物融合型エンジニアリング専門委員会

（24）マイクロ生産機械システム専門委員会

(25) 知的ナノ計測専門委員会

（26）微細加工と表面機能専門委員会

（27）静岡県東部精密技術専門委員会

（28）静岡県西部地区精密技術専門委員会

$<2012$ 年度に設置の専門委員会 $>$

（1）大規模環境の 3 次元計測と認識・モデル化技術専門委員会

＜2012年度に設置予定＞

数件 


\section{II 精密工学に関する講演会等関連事業（定款 4 条 1 項 (2)）・・・・・・公 2 】}

(1) 研究発表会、講演会、講習会等の開催

2012年度精密工学会春季大会を下記のとおり行う。
日時
平成24年3月 14 日〜平成24年3月 16 日
場所
首都大学東京 南大沢キャンパス
参加予定者数 1,300 人 演題数 595 件

第19回学生会員卒業研究発表会を下記のとおり行う。
日時
平成24年3月 14 日
場所＼cjkstart首都大学東京 南大沢キャンパス
参加予定者数
80 人 演題数 74 件

2012年度精密工学会秋季大会を下記のとおり行う。

日時 平成24年9月14日〜平成24年9月16日

場所 九州工業大学 戸畑キャンパス

参加予定者数 1,200 人 演題数 500 件

ICPE2012を開催する。

$\begin{array}{ll}\text { 日時 } & \text { 平成24年 } 1 \text { 月 } 1 \text { 日日 10日 } \\ \text { 場所 } & \text { 淡路夢舞台国際会議場 }\end{array}$

10th ICPMTを共催する。

$\begin{array}{ll}\text { 日時 } & \text { 平成24年9月25日〜9月27日 } \\ \text { 場所 } & \text { 燕三条地場産業振興センター }\end{array}$

ICPT2012を共催する。

日時平成24年11月14日～16日

場所台湾高雄市

Designシンポジウム2012を共催する。

日時平成24年7月または11月

場所京都大学

講習会の実施 : 6回／年開催

その他各支部講演会、他学会との共催講演会等を行う。

(2) 内外の関係団体との連携等

国内共催事業社)日本機械学会共催講演会を行う。

幾つかの学会連合での講演会、シンポジウムを行う。

日本学術会議、関連学協会催事に対する協賛、後援を行う。

国際交流

IPS2（11月8日～9日、東京）に企画協力する。

その他国際会議を数件行う。

吕精密工学に関する奨励・顕彰等事業（定款 4 条 1 項 (3)) …・・・・【公 3 】

(1) 表彰に関する事項

1. 精密工学会論文賞 （1）2011年度精密工学会論文賞の審査および贈賞

贈賞式 平成24年3月15日（木）首都大学東京 南大沢キャンパス

（2）2012年度精密工学会論文賞の審査

2. 精密工学会研究 奨励賞

（1）2011年度精密工学会研究奨励賞の審査および贈賞

贈賞式 平成24年3月15日（木）首都大学東京 南大沢キャンパス

（2）2012年度精密工学会研究奨励賞の審査

3. 精密工学会沼田

（1）2011年度精密工学会沼田記念論文賞の審査および贈賞

記念論文賞

贈賞式 平成24年3月15日（木）

首都大学東京 南大沢キャンパス

（2）2012年度精密工学会沼田記念論文賞の審査

4. 精密工学会高城賞 （1）2011年度精密工学会高城賞の審査および贈賞

贈賞式 平成24年3月15日（木）首都大学東京 南大沢キャンパス

（2）2012年度精密工学会高城賞の審査

5. 精密工学会賞

（1）2012年度精密工学会賞の審査および贈賞

贈賞式 平成24年9月15日（土） 九州工業大学 戸畑キャンパス 
6. 精密工学会技術賞 （1）2012年度精密工学会技術賞の審査および贈賞

$$
\text { 贈賞式 平成 } 24 \text { 年9月15日（土） 九州工業大学 戸畑キャンパス }
$$

7. 精密工学会技術 （1）2012年度精密工学会技術奨励賞の審査および贈賞

奨励賞

贈賞式 平成24年9月15日（土） 九州工業大学

IV その他本法人の目的を達成するために必要な事業（定款 4 条 1 項 (4))

(1) 会議等に関する事項

1. 社員総会

2. 理事会

3. 業務執行委員会

4. 代議員会議

5. 支部会議

6. 支部長会議

7. 支部・本部懇談会

8. 専門委員長会議

9. 『賛助会員の会』

(2) 委員会に関寸る事項

1. 事業に関する委員会

2. 出版に関する委員会

2012年度定時社員総会

2012年度理事会

2012年度業務執行委員会

2012年度代議員会議

2012年度支部商議員会議、総会

2012年度支部長会議

2012年度支部・本部懇談会

2012年度専門委員長会議

2012年度総会及びテクノフォーラム
3月15日（木）

6 回開催

4 回開催

9月15日（土）九州工業大学

各支部にて開催

3月14日 (火) 首都大学東京

9月14日（金） 九州工業大学

3月15日（木）首都大学東京

3月15日、9月15日 首都大学東京、九州工業大学

事業部会

1）事業企画委員会

2）研究協力委員会

3）学術交流委員会

4）国際交流委員会

5）アフィリエイト委員会

出版部会

1）会誌編集委員会

2）校閲委員会

3．広報・情報に関する委員会

広報・情報部会

1）広報委員会

2）情報化委員会

4. 賞に関する委員会 （1）精密工学会賞推薦委員会、審査委員会

（2）精密工学会論文賞審查委員会

（3）精密工学会研究奨励賞審査委員会

（4）精密工学会技術賞審査委員会

（5）精密工学会技術奨励賞審査委員会

（6）精密工学会沼田記念論文賞審查委員会

（7）精密工学会高城賞審査委員会

5. その他の委員会

(1) 理事会WG

（2）精密工学会フェロー選考委員会

（3）精密工学会アフィリエイト選考委員会

（4）精密工学会「賛助会員の会」運営委員会 
議案5 2012年度収支予算の件

（1） 2012 年度 (平成24年度) 収支予算書

2012年 2月 1日から2013年 1月31日まで（単位:円）

\begin{tabular}{|c|c|c|c|}
\hline 科 目 & 当期予算額 & 前期予算額 & 差 異 \\
\hline 〔事業活動収支の部〕 & & & \\
\hline 【基本財産運用収入】 & $\underline{44,146}$ & $\underline{86,075}$ & $\triangle 41,929$ \\
\hline 基本財産受取利息収入 & $\overline{44,146}$ & $\overline{86,075}$ & $\triangle 41,929$ \\
\hline 【受取入会金収入】 & $\underline{105,000}$ & $\underline{110,000}$ & $\triangle 5,000$ \\
\hline 入会金収入 & 105,000 & 110,000 & $\triangle 5,000$ \\
\hline 【受取会費収入】 & $\underline{86,790,000}$ & $\underline{88,540,000}$ & $\triangle 1,750,000$ \\
\hline 正会員会費収入 & $48,340,000$ & $49,845,000$ & $\triangle 1,505,000$ \\
\hline 賛助会員会費収入 & $34,750,000$ & $34,695,000$ & 55,000 \\
\hline 学生会員会費収入 & $3,700,000$ & $4,000,000$ & $\triangle 300,000$ \\
\hline 【調査研究分担金収入】 & $\underline{47,392,000}$ & $\underline{47,277,000}$ & $\underline{115,000}$ \\
\hline 調査研究分担金収入·個人会費 & $3,682,000$ & $3,597,000$ & 85,000 \\
\hline 調査研究分担金収入•法人会費等 & $43,710,000$ & $43,680,000$ & 30,000 \\
\hline 【出版事業収入】 & $\underline{24,760,000}$ & $\underline{26,890,000}$ & $\triangle 2,130,000$ \\
\hline 会誌広告料収入 & $5,500,000$ & $5,500,000$ & 0 \\
\hline 論文掲載料収入 & $10,000,000$ & $12,240,000$ & $\triangle 2,240,000$ \\
\hline 会誌購読料収入 & $5,000,000$ & $5,000,000$ & 0 \\
\hline PE誌購読料収入 & $1,000,000$ & $1,000,000$ & 0 \\
\hline 別刷代収入 & 860,000 & $1,380,000$ & $\triangle 520,000$ \\
\hline 有料収入会告料収入 & $1,000,000$ & 720,000 & 280,000 \\
\hline 著作権料収入 & $1,400,000$ & $1,050,000$ & 350,000 \\
\hline 【講演会事業収入】 & $\underline{71,576,000}$ & $\underline{48,584,000}$ & $\underline{22,992,000}$ \\
\hline 学術講演会収入 & $19,225,000$ & $18,532,000$ & 693,000 \\
\hline 春季大会収入 & $12,995,000$ & $12,830,000$ & 165,000 \\
\hline 秋季大会収入 & $16,526,000$ & $14,500,000$ & $2,026,000$ \\
\hline 講習会収入 & $2,500,000$ & $2,660,000$ & $\triangle 160,000$ \\
\hline 国際会議収入 & $20,250,000$ & 0 & $20,250,000$ \\
\hline 賛助会員の会収入 & 80,000 & 62,000 & 18,000 \\
\hline 研究会活動分担金収入 & 0 & & 0 \\
\hline 【特別事業収入】 & $\underline{0}$ & $\underline{700,000}$ & $\triangle 700,000$ \\
\hline 周年行事収入 & 0 & 700,000 & $\triangle 700,000$ \\
\hline 【広報·情報事業収入】 & $\underline{896,400}$ & $\underline{768,900}$ & $\underline{127,500}$ \\
\hline HP広告掲載料収入 & 896,400 & 768,900 & 127,500 \\
\hline 【事業管理収入】 & $\underline{920,000}$ & $\underline{900,000}$ & $\underline{20,000}$ \\
\hline 事務分担金収入 & 900,000 & 900,000 & 0 \\
\hline 頒布手数料収入 & 20,000 & 0 & 20,000 \\
\hline 【受取補助金等収入】 & $\underline{1,230,000}$ & $\underline{1,450,000}$ & $\triangle 220,000$ \\
\hline 国·地方自治体補助金収入 & 0 & 100,000 & $\triangle 100,000$ \\
\hline 国・地方自治体助成金収入 & 0 & 0 & 0 \\
\hline 財団法人等補助金収入 & $1,230,000$ & $1,350,000$ & $\triangle 120,000$ \\
\hline 一般寄付金等収入 & 0 & 0 & 0 \\
\hline 【雑収入】 & $\underline{260,612}$ & $\underline{296,928}$ & $\triangle 36,316$ \\
\hline 運用財産受取利息収入 & 110,612 & 216,928 & $\triangle 106,316$ \\
\hline 雑収入 & 30,000 & 30,000 & 0 \\
\hline 削除者会費収入 & 120,000 & 50,000 & 70,000 \\
\hline 事業活動収入計 & $233,974,158$ & $215,602,903$ & $18,371,255$ \\
\hline 【出版事業費支出】 & $37,360,000$ & $47,933,500$ & $\triangle 10,573,500$ \\
\hline 〔出版部会費支出〕 & 570,000 & 640,000 & $\triangle 70,000$ \\
\hline 〔編集委員会費支出〕 & $32,920,000$ & $38,233,000$ & $\triangle 5,313,000$ \\
\hline [校閲委員会費支出] & 750,000 & $2,197,000$ & $\triangle 1,447,000$ \\
\hline 〔編集管理費支出〕 & $1,550,000$ & $4,643,500$ & $\triangle 3,093,500$ \\
\hline 〔PE購読費支出〕 & $1,570,000$ & $2,220,000$ & $\triangle 650,000$ \\
\hline 【講演会事業費支出】 & $\underline{140,223,234}$ & $\underline{115,188,740}$ & $\underline{25,034,494}$ \\
\hline 学術講演会等事業費支出 & $76,446,089$ & $79,443,740$ & $\triangle 2,997,651$ \\
\hline 事業部会費支出 & $1,865,000$ & $1,060,000$ & 805,000 \\
\hline 活動支援費支出 & 785,000 & 695,000 & 90,000 \\
\hline 関連諸経費支出 & 580,000 & 780,000 & $\triangle 200,000$ \\
\hline 春季大会費支出 & $9,300,000$ & $9,250,000$ & 50,000 \\
\hline 秋季大会費支出 & $16,160,555$ & $15,400,000$ & 760,555 \\
\hline 講習会費支出 & $1,870,000$ & $1,610,000$ & 260,000 \\
\hline 国際会議費支出 & $27,816,590$ & $1,350,000$ & $26,466,590$ \\
\hline 研究会運営費支出 & 0 & 200,000 & $\triangle 200,000$ \\
\hline 業務委託費支出 & $5,400,000$ & $5,400,000$ & 0 \\
\hline
\end{tabular}




\begin{tabular}{|c|c|c|c|}
\hline 科 目 & 当期予算額 & 前期予算額 & 差 異 \\
\hline 【特別事業費支出】 & $3,100,000$ & $\underline{3,080,000}$ & $\underline{20,000}$ \\
\hline 周年行事費支出 & $3,100,000$ & $3,080,000$ & 20,000 \\
\hline 【広報・情報事業費支出】 & $\underline{2,307,643}$ & $\underline{2,847,400}$ & $\triangle 539,757$ \\
\hline 〔広報部会費支出〕 & $\overline{1,226,333}$ & $1,027,000$ & 199,333 \\
\hline 〔情報関連費支出〕 & $1,081,310$ & $1,820,400$ & $\triangle 739,090$ \\
\hline 【表彰費支出】 & $\underline{2,920,000}$ & $\underline{2,920,000}$ & $\underline{0}$ \\
\hline 【事業費支出】 & $\underline{55,764,738}$ & $\underline{56,839,138}$ & $\triangle 1,074,400$ \\
\hline 〔事業人件費〕 & $32,652,910$ & $34,087,310$ & $\triangle 1,434,400$ \\
\hline 〔会員管理費支出〕 & $3,480,000$ & $3,317,000$ & 163,000 \\
\hline 〔事業諸経費支出] & $19,631,828$ & $19,434,828$ & 197,000 \\
\hline 【管理費支出】 & $\underline{12,501,032}$ & $\underline{12,513,001}$ & $\triangle 11,969$ \\
\hline [管理人件費支出] & $6,911,482$ & $6,869,416$ & 42,066 \\
\hline 〔理事会費支出〕 & $4,080,000$ & $3,840,000$ & 240,000 \\
\hline [その他管理費支出] & $1,509,550$ & $1,803,585$ & $\triangle 294,035$ \\
\hline 事業活動支出計 & $254,176,647$ & $241,321,779$ & $12,854,868$ \\
\hline 事業活動収支差額 & $\triangle 20,202,489$ & $\triangle 25,718,876$ & $5,516,387$ \\
\hline 〔投資活動収支の部〕 & & & \\
\hline 【特定資産取崩収入】 & $\underline{23,700,000}$ & $\underline{18,050,000}$ & $\underline{5,650,000}$ \\
\hline (特定引当資産及び組替前積立資産) & 0 & 0 & 0 \\
\hline 退職給付引当資産取崩収入 & & & 0 \\
\hline 【特定積立資産 (A)取崩収入】 & 0 & 0 & 0 \\
\hline 会員DBシステム更改用積立資産取崩収入 & & & 0 \\
\hline オフィスPC更改用積立資産取崩収入 & & & 0 \\
\hline 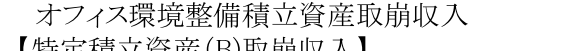 & & & $\begin{array}{rr}0 \\
18000000\end{array}$ \\
\hline 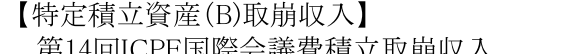 & $\frac{18,000,000}{15000000}$ & $\underline{0}$ & $\frac{18,000,000}{15,000,000}$ \\
\hline $\begin{array}{l}\text { 第14回ICPE国際会議費積立取崩収入 } \\
\text { 精密工学会85奝年事業費積立取崩収入 }\end{array}$ & $15,000,000$ & 0 & $\begin{array}{r}15,000,000 \\
0\end{array}$ \\
\hline 第6回ASPEN国際会議費積立取崩収入 & & & 0 \\
\hline 東海支部60周年記念事業積立資産取崩収入 & $3,000,000$ & 0 & $3,000,000$ \\
\hline $\begin{array}{l}\text { 専門委員会等活動費積立資産取崩収入 } \\
\text { 【その他積立固定資産取崩収】 }\end{array}$ & & & $\begin{array}{r}0 \\
0\end{array}$ \\
\hline $\begin{array}{l}\text { 【その他積立固定資産取崩収入】 } \\
\text { 资金平淮化皘立瓷産取崩収入 }\end{array}$ & $\underline{5,700,000}$ & $\underline{18,050,000}$ & $\triangle 12,350,000$ \\
\hline $\begin{array}{l}\text { 資金平隻化積立資産取崩収入 } \\
\text { 特別事業積立資産取崩収入 }\end{array}$ & & $10,000,000$ & $\triangle 10,000,000$ \\
\hline $\begin{array}{l}\text { 特別事業積立資産取崩収入 } \\
\text { 事務研修積立資産取崩収入 }\end{array}$ & & & 0 \\
\hline $\begin{array}{l}\text { 事務研修樍立資産取朋収人 } \\
\text { 事務近代化積立資産取崩収入 }\end{array}$ & & & 0 \\
\hline 支部活動費積立資産取崩収入 & $1,200,000$ & $6,850,000$ & $\triangle 5,650,000$ \\
\hline 専門委員会等活動費積立資産取崩収入 & $4,500,000$ & $1,200,000$ & $3,300,000$ \\
\hline 投資活動収入計 & $23,700,000$ & $18,050,000$ & $5,650,000$ \\
\hline 【特定資産取得支出】 & $10,831,120$ & $9,151,080$ & $1,680,040$ \\
\hline （特定引当資産及び組替前積立資産） & $\underline{801,120}$ & $\underline{721,080}$ & $\underline{80,040}$ \\
\hline 退職給付引当資産取得支出 & $\overline{801,120}$ & $\overline{721,080}$ & $\overline{80,040}$ \\
\hline 【特定積立資産(A)取得支出】 & $\underline{1,550,000}$ & $\underline{1,550,000}$ & $\underline{0}$ \\
\hline 会員DBシステム更改用積立資産取得支出 & 750,000 & 750,000 & 0 \\
\hline オフィスPC更改用積立資産取得支出 & 250,000 & 250,000 & 0 \\
\hline オフィス環境整備積立資産取得支出 & 550,000 & 550,000 & 0 \\
\hline 【特定積立資産(B)取得支出】 & $\underline{5,080,000}$ & $\underline{6,580,000}$ & $\triangle 1,500,000$ \\
\hline 第14回ICPE国際会議費積立支出 & $2,500,000$ & $2,500,000$ & 0 \\
\hline 精密工学会85周年事業費資金積立支出 & $1,500,000$ & $1,500,000$ & 0 \\
\hline 第6回ASPEN国際会議費積立支出 & $1,080,000$ & $1,080,000$ & 0 \\
\hline 東海支部60周年記念事業積立支出 & 0 & $1,500,000$ & $\triangle 1,500,000$ \\
\hline 支部活動費積立資産取得支出 & & & 0 \\
\hline 専門委員会等活動費積立資産取得支出 & & & 0 \\
\hline 【その他積立固定資産取得支出】 & $\underline{3,400,000}$ & $\underline{300,000}$ & $\underline{3,100,000}$ \\
\hline 資金平準化積立資産取得支出 & & & 0 \\
\hline 特別事業積立資産取得支出 & & & 0 \\
\hline 事務研修積立資産取得支出 & & & 0 \\
\hline 事務近代化積立資産取得支出 & & & 0 \\
\hline 支部活動費積立資産取得支出 & $3,400,000$ & 300,000 & $3,100,000$ \\
\hline 専門委員会等活動費積立資産取得支出 & 0 & 0 & 0 \\
\hline 投資活動支出計 & $10,831,120$ & $9,151,080$ & $1,680,040$ \\
\hline 投資活動収支差額 & $12,868,880$ & $8,898,920$ & $3,969,960$ \\
\hline 【予備費支出】 & 0 & 0 & 0 \\
\hline 当期収支差額 & $\triangle 7,333,609$ & $\triangle 16,819,956$ & $9,486,347$ \\
\hline 前期繰越収支差額 & $82,555,370$ & $75,455,711$ & $7,099,659$ \\
\hline 次期繰越収支差額 & $75,221,761$ & $58,635,755$ & $16,586,006$ \\
\hline
\end{tabular}

特定積立資産 $(\mathrm{A})$ は特定資産取得資金、特定積立資産 $(B)$ は特定費用準備資金 
（2） 2012年度 (平成24年度)収支予算書 総括表

2012年2月 1日から 2013 年1月31日まで（単位:円）

\begin{tabular}{|c|c|c|c|c|c|c|}
\hline \multirow[t]{2}{*}{ 科目 } & \multirow{2}{*}{$\begin{array}{l}\text { 本部 } \\
\text { 会計 }\end{array}$} & \multirow{2}{*}{$\begin{array}{l}\text { 支部 } \\
\text { 会計 }\end{array}$} & \multirow{2}{*}{$\begin{array}{c}\text { 専門委員会 } \\
\text { 会計 }\end{array}$} & \multicolumn{2}{|c|}{ 内部取引調整額 } & \multirow[t]{2}{*}{ 合 計 } \\
\hline & & & & 借方 & 貸方 & \\
\hline \multicolumn{7}{|l|}{ 事業活動収支の部 } \\
\hline 基本財産利息収入 & 44,146 & & & & & 44,146 \\
\hline 入会金·会費収入 & $86,895,000$ & & & & & $86,895,000$ \\
\hline 支部活動費受入金収入 & & $7,498,000$ & & $7,498,000$ & & 0 \\
\hline 調查研究分担金収入 & & & $47,392,000$ & & & $47,392,000$ \\
\hline 出版事業収入 & $24,760,000$ & & & & & $24,760,000$ \\
\hline 講演会事業収入 & $37,966,700$ & $23,426,000$ & $14,375,000$ & $4,191,700$ & & $71,576,000$ \\
\hline \multicolumn{7}{|l|}{ 特別事業収入 } \\
\hline 広報・情報事業収入 & 896,400 & & & & & 896,400 \\
\hline 事業管理収入 & $1,270,000$ & & & 350,000 & & 920,000 \\
\hline 補助金等収入 & $1,230,000$ & & & & & $1,230,000$ \\
\hline 雑収入 & 244,000 & 4,465 & 12,147 & & & 260,612 \\
\hline 繰入金収入 & $3,400,000$ & $4,200,000$ & $4,500,000$ & $12,100,000$ & & 0 \\
\hline 事業活動収入計 & $156,706,246$ & $35,128,465$ & $66,279,147$ & $24,139,700$ & 0 & $233,974,158$ \\
\hline 出版事業費支出 & $37,360,000$ & & & & & $37,360,000$ \\
\hline 講演会事業費支出 & $40,076,590$ & $31,268,045$ & $74,310,299$ & & $5,431,700$ & $140,223,234$ \\
\hline 特別事業費支出 & & $3,000,000$ & 100,000 & & & $3,100,000$ \\
\hline 広報·情報事業費支出 & $2,307,643$ & & & & & $2,307,643$ \\
\hline 表彰費支出 & $2,920,000$ & & & & & $2,920,000$ \\
\hline 事業費支出 & $62,372,738$ & & & & $6,608,000$ & $55,764,738$ \\
\hline 管理費支出 & $11,129,282$ & 226,050 & $1,145,700$ & & & $12,501,032$ \\
\hline \multicolumn{7}{|l|}{ その他支出 } \\
\hline 繰入金支出 & $8,700,000$ & $3,400,000$ & 0 & & $12,100,000$ & 0 \\
\hline 事業活動支出計 & $164,866,253$ & $37,894,095$ & $75,555,999$ & 0 & $24,139,700$ & $254,176,647$ \\
\hline 事業活動収支差額 & $\triangle 8,160,007$ & $\triangle 2,765,630$ & $\triangle 9,276,852$ & & & $\triangle 20,202,489$ \\
\hline \multicolumn{7}{|l|}{ 投資活動収支の部 } \\
\hline 特定積立資産取崩収入 (B) & $18,000,000$ & & & & & $18,000,000$ \\
\hline その他積立固定資産取崩収入 & $5,700,000$ & & & & & $5,700,000$ \\
\hline \multicolumn{7}{|l|}{ 基本財産取得支出 } \\
\hline 特定引当資産取得支出 & 801,120 & & & & & 801,120 \\
\hline 特定積立資産取得支出 (A) & $1,550,000$ & & & & & $1,550,000$ \\
\hline 特定積立資産取得支出 (B) & $5,080,000$ & & & & & $5,080,000$ \\
\hline その他積立固定資産取得支出 & $3,400,000$ & & & & & $3,400,000$ \\
\hline 投資活動収入計 & $23,700,000$ & 0 & 0 & & & $23,700,000$ \\
\hline 投資活動支出計 & $10,831,120$ & 0 & 0 & & & $10,831,120$ \\
\hline 投資活動収支差額 & $12,868,880$ & 0 & 0 & & & $12,868,880$ \\
\hline 予備費支出 & 0 & & & & & 0 \\
\hline 当期収支差額 & $4,708,873$ & $\triangle 2,765,630$ & $\triangle 9,276,852$ & & & $\triangle 7,333,609$ \\
\hline 前期繰越収支差額 & $31,788,250$ & $11,079,187$ & $39,687,933$ & & & $82,555,370$ \\
\hline 次期繰越収支差額 & $36,497,123$ & $8,313,557$ & $30,411,081$ & & & $75,221,761$ \\
\hline
\end{tabular}


（3） 2012年度 (平成24年度） 正味財産増減予算書

（2012年 2月 1日から2013年 1月31日まで）

(単位:円)

\begin{tabular}{|c|c|c|c|}
\hline 科 & 当期予算額 & 前期予算額 & 増 \\
\hline \multicolumn{4}{|l|}{ [一般正味財産増減の部] } \\
\hline 〔経常増減の部〕 ～～～～ & & & \\
\hline & & & \\
\hline 【基本財産運用益】 & $\underline{44,146}$ & $\underline{86,075}$ & $\triangle 41,929$ \\
\hline 基本財産受取利息 & 44,146 & 86,075 & $\triangle 41,929$ \\
\hline 【受取入会金】 & $\underline{105,000}$ & $\underline{110,000}$ & $\triangle 5,000$ \\
\hline 入会金 & 105,000 & 110,000 & $\triangle 5,000$ \\
\hline 【受取会費】 & $\underline{86,790,000}$ & $\underline{88,540,000}$ & $\triangle 1,750,000$ \\
\hline 正会員会費 & $48,340,000$ & $49,845,000$ & $\triangle 1,505,000$ \\
\hline 賛助会員会費 & $34,750,000$ & $34,695,000$ & 55,000 \\
\hline 学生会員会費 & $3,700,000$ & $4,000,000$ & $\triangle 300,000$ \\
\hline 【調査研究分担金収入】 & $\underline{47,392,000}$ & $\underline{47,277,000}$ & $\underline{115,000}$ \\
\hline 調査研究分担金収入·個人会員 & $3,682,000$ & $3,597,000$ & 85,000 \\
\hline 調査研究分担金収入·法人会員 & $43,710,000$ & $43,680,000$ & 30,000 \\
\hline 【出版事業収益】 & $\underline{24,760,000}$ & $\underline{26,890,000}$ & $\triangle 2,130,000$ \\
\hline 会誌広告料 & $5,500,000$ & $5,500,000$ & 0 \\
\hline 論文掲載料 & $10,000,000$ & $12,240,000$ & $\triangle 2,240,000$ \\
\hline 会誌購読料 & $5,000,000$ & $5,000,000$ & 0 \\
\hline PE誌購読料 & $1,000,000$ & $1,000,000$ & 0 \\
\hline 別刷代 & 860,000 & $1,380,000$ & $\triangle 520,000$ \\
\hline 有料会告料 & $1,000,000$ & 720,000 & 280,000 \\
\hline 著作権料 & $1,400,000$ & $1,050,000$ & 350,000 \\
\hline 【講演会事業収益】 & $\underline{71,576,000}$ & $\underline{48,584,000}$ & $\underline{22,992,000}$ \\
\hline 学術講演会 & $19,225,000$ & $18,532,000$ & 693,000 \\
\hline 春季大会 & $12,995,000$ & $12,830,000$ & 165,000 \\
\hline 秋季大会 & $16,526,000$ & $14,500,000$ & $2,026,000$ \\
\hline 講習会 & $2,500,000$ & $2,660,000$ & $\triangle 160,000$ \\
\hline 国際会議 & $20,250,000$ & 0 & $20,250,000$ \\
\hline 賛助会員の会 & 80,000 & 62,000 & 18,000 \\
\hline 【特別事業収益】 & $\underline{0}$ & $\underline{700,000}$ & $\triangle 700,000$ \\
\hline 周年行事収入 & 0 & 700,000 & $\triangle 700,000$ \\
\hline 特別事業収入 & 0 & 0 & 0 \\
\hline 【広報·情報事業収益】 & 896,400 & $\underline{768,900}$ & $\underline{127,500}$ \\
\hline HP広告掲載料 & 896,400 & 768,900 & 127,500 \\
\hline 【事業管理収益】 & $\underline{920,000}$ & $\underline{900,000}$ & $\underline{20,000}$ \\
\hline 事務分担金 & 900,000 & 900,000 & 0 \\
\hline 頒布手数料 & 20,000 & 0 & 20,000 \\
\hline 【受取補助金等】 & $\underline{1,230,000}$ & $\underline{1,450,000}$ & $\triangle 220,000$ \\
\hline 国·地方自治体等補助金 & 0 & 100,000 & $\triangle 100,000$ \\
\hline 国·地方自治体等助成金 & 0 & 0 & 0 \\
\hline 財団法人等補助金 & $1,230,000$ & $1,350,000$ & $\triangle 120,000$ \\
\hline 一般寄付金等 & 0 & 0 & 0 \\
\hline 【雑収益】 & $\underline{260,612}$ & $\underline{296,928}$ & $\triangle 36,316$ \\
\hline 運用財産受取利息 & 110,612 & 216,928 & $\triangle 106,316$ \\
\hline 雑収益 & 30,000 & 30,000 & 0 \\
\hline 削除者会費 & 120,000 & 50,000 & 70,000 \\
\hline 経常収益計 & $233,974,158$ & $215,602,903$ & $18,371,255$ \\
\hline
\end{tabular}




\begin{tabular}{|c|c|c|c|}
\hline 科 & 当期予算額 & 前期予算額 & 増 \\
\hline \multicolumn{4}{|l|}{ 〔経常費用〕 } \\
\hline 【出版事業費】 & $\underline{37,360,000}$ & $\underline{47,933,500}$ & $\triangle 10,573,500$ \\
\hline 〔出版部会費〕 & 570,000 & 640,000 & $\triangle 70,000$ \\
\hline 〔編集委員会費〕 & $32,920,000$ & $38,233,000$ & $\triangle 5,313,000$ \\
\hline 〔校閲委員会費〕 & 750,000 & $2,197,000$ & $\triangle 1,447,000$ \\
\hline 〔編集管理費〕 & $1,550,000$ & $4,643,500$ & $\triangle 3,093,500$ \\
\hline 〔PE購読費〕 & $1,570,000$ & $2,220,000$ & $\triangle 650,000$ \\
\hline 【講演会事業費】 & $140,223,234$ & $\underline{115,188,740}$ & $25,034,494$ \\
\hline 学術講演会等費 & $76,446,089$ & $79,443,740$ & $\triangle 2,997,651$ \\
\hline 事業部会費 & $1,865,000$ & $1,060,000$ & 805,000 \\
\hline 活動支援費 & 785,000 & 695,000 & 90,000 \\
\hline 関連諸経費 & 580,000 & 780,000 & $\triangle 200,000$ \\
\hline 春季大会費 & $9,300,000$ & $9,250,000$ & 50,000 \\
\hline 秋季大会費 & $16,160,555$ & $15,400,000$ & 760,555 \\
\hline 講習会 & $1,870,000$ & $1,610,000$ & 260,000 \\
\hline 国際会議費 & $27,816,590$ & $1,350,000$ & $26,466,590$ \\
\hline 研究会運営費 & 0 & 200,000 & $\triangle 200,000$ \\
\hline 業務委託費 & $5,400,000$ & $5,400,000$ & 0 \\
\hline 【特別事業費】 & $3,100,000$ & $\underline{3,080,000}$ & 20,000 \\
\hline 周年行事費 & $3,100,000$ & $3,080,000$ & 20,000 \\
\hline 特別事業費 & 0 & 0 & 0 \\
\hline 【広報・情報事業費】 & $\underline{2,307,643}$ & $\underline{2,847,400}$ & $\triangle 539,757$ \\
\hline 〔広報部会費〕 & $1,226,333$ & $1,027,000$ & 199,333 \\
\hline 〔情報関連費〕 & $1,081,310$ & $1,820,400$ & $\triangle 739,090$ \\
\hline 【表彰費】 & $\underline{2,920,000}$ & $\underline{2,920,000}$ & $\underline{0}$ \\
\hline 【事業費】 & $\underline{56,000,388}$ & $\underline{57,423,340}$ & $\triangle 1,422,952$ \\
\hline [事業人件費] & $32,652,910$ & $34,087,310$ & $\triangle 1,434,400$ \\
\hline 〔会員管理費〕 & $3,480,000$ & $3,317,000$ & 163,000 \\
\hline 〔事業諸経費〕 & $19,867,478$ & $20,019,030$ & $\triangle 151,552$ \\
\hline 【管理費】 & $\underline{12,501,032}$ & $\underline{12,513,001}$ & $\triangle 11,969$ \\
\hline 〔管理人件費〕 & $6,911,482$ & $6,869,416$ & 42,066 \\
\hline 〔理事会費〕 & $4,080,000$ & $3,840,000$ & 240,000 \\
\hline [その他管理費] & $1,509,550$ & $1,803,585$ & $\triangle 294,035$ \\
\hline 経常費用計 & $254,412,297$ & $241,905,981$ & $12,506,316$ \\
\hline 当期経常増減額 & $\triangle 20,438,139$ & $\triangle 26,303,078$ & $5,864,939$ \\
\hline \multicolumn{4}{|l|}{ 〔経常外増減の部〕 } \\
\hline \multicolumn{4}{|l|}{ 〔経常外収益〕 } \\
\hline 【引当金取崩額】 & 445,600 & 544,800 & $\triangle 99,200$ \\
\hline 退職給付引当金取崩額 & 0 & 0 & 0 \\
\hline 会費回収不能引当金取崩額 & 445,600 & 544,800 & $\triangle 99,200$ \\
\hline 経常外収益計 & 445,600 & 544,800 & $\triangle 99,200$ \\
\hline \multicolumn{4}{|l|}{ 〔経常外費用〕 } \\
\hline 【引当金繰入額】 & $1,233,270$ & $1,229,380$ & 3,890 \\
\hline 退職給付引当金繰入額 & 801,120 & 721,080 & 80,040 \\
\hline 会費回収不能引当金繰入額 & 432,150 & 508,300 & $\triangle 76,150$ \\
\hline 経常外費用計 & $1,233,270$ & $1,229,380$ & 3,890 \\
\hline 当期経常外増減額 & $\triangle 787,670$ & $\triangle 684,580$ & $\triangle 103,090$ \\
\hline 税引き前当期一般正味財産増減額 & $\triangle 21,225,809$ & $\triangle 26,987,658$ & $5,761,849$ \\
\hline 当期一般正味財産増減額 & $\triangle 21,225,809$ & $\triangle 26,987,658$ & $5,761,849$ \\
\hline 一般正味財産期首残高 & $247,477,551$ & $248,906,024$ & $\triangle 1,428,473$ \\
\hline 一般正味財産期末残高 & $226,251,742$ & $221,918,366$ & $4,333,376$ \\
\hline \multicolumn{4}{|l|}{ 〔指定正味財産の部] } \\
\hline 当期指定正味財産増加額 & 0 & 0 & 0 \\
\hline 当期指定正味財産減少額 & 0 & 0 & 0 \\
\hline 当期正味財産期首残高 & 0 & 0 & 0 \\
\hline 指定正味財産期末残高 & 0 & 0 & 0 \\
\hline 正味財産期末残高 & $226,251,742$ & $221,918,366$ & $4,333,376$ \\
\hline
\end{tabular}

\section{議案6 名誉会員推薦の件}

名誉会員候補者

稲崎一郎氏 小林 明発氏 嘉数 侑昇氏 